\title{
Natural Hedging of Exchange Rate Risk: The Role of Imported Input Prices
}

\author{
Dario Fauceglia ${ }^{a}$, Anirudh Shingal ${ }^{b}$, and Martin Wermelinger ${ }^{c}$
}

JEL-Classification: F31, F41

Keywords: exchange rates, exchange rate pass-through, international trade, prices

\section{Introduction}

The exchange rate pass-through (ERPT) literature has paid little attention to the exchange rate sensitivity of imported input prices. This issue is important for two reasons. First, adjustments of marginal costs due to exchange rate changes could explain part of the low ERPT generally observed in the data (see BuRsTEIN and GopINATH, 2013). The related rationale for studying this marginal cost channel is the potential role of imported inputs as a tool to "naturally" hedge exchange rate risks; exporters may have the means to offset some of the adverse effect of exchange rate appreciations on profit margins through cheaper imported inputs. However, this natural hedging is only effective if imported input prices vary strongly with exchange rates. In other words, a high pass-through into imported input prices is required for effective natural hedging. This paper also studies ERPT on the export side and examines whether imported input cost changes are passed on to foreign consumers.

It turns out that the recent empirical literature mainly focuses on (semi-) final goods price adjustments and investigates the cost effect due to imported inputs using interaction terms in the export price equation between the ratio of total imports to total sales or costs and the exchange rate (Аміті, Iтsкнокі and Konings, 2012; and Berman, Martin and Mayer, 2012). In contrast, we employ an imported input weighted exchange rate that takes into account the origin of inputs to capture changes in imported input costs related to exchange rate movements, as done in Greenaway, Kneller and Zhang (2010). In a

a University of St. Gallen and Zurich University of Applied Sciences. Email: dario.fauceglia@ unisg.ch.

b World Trade Institute, University of Bern. Email: anirudh.shingal@wti.org.

c University of St. Gallen. Email: martin.wermelinger@unisg.ch. 
significant departure from this literature, we also look in detail at actual price developments of imported inputs as a result of exchange rate shocks.

In this paper, we study ERPT into imported input prices and export prices (in Swiss Francs (CHF)) using bilateral and disaggregated unit values as proxies for prices. First, to study the effectiveness of "natural hedging" of exchange rate risk, we quantify the effect of exchange rate fluctuations on these imported input prices. Next, we examine total pass-through effects on export prices; that is the combined effect of pricing to market and cost adjustments via imported input prices on export prices when the exchange rate fluctuates. While the first step also provides insights on the potential contribution of the marginal cost or imported input channel in generating incomplete ERPT, the second step reveals how exporters' profit margins react to bilateral exchange rate and imported input cost changes.

We use quarterly product level trade data at the HS 8-digit level for Switzerland between 2004 and 2011 in our analyses. Analysing imported input prices in Switzerland is particularly interesting as the Swiss economy has high ratios of imported intermediate inputs relative to total intermediate inputs, especially in the manufacturing sector (see Table 3), and about half of total imports are processed and re-exported (see SECO, 2011). In the event of significant "natural hedging" it is thus a relevant question whether Swiss exporters are (at least to some extent) spared from losing competitive advantage despite the strong appreciation of the CHF. Last but not least, investigating this issue with Swiss data also contributes to the topical debate on the "strong" CHF. According to a study by the State Secretariat for Economic Affairs (SECO, 2011), imported goods prices fell by $40 \%$ three or four quarters after the appreciation. However, the prices did not fall as much as the CHF appreciated. While the focus of that discussion was more related to imported consumer goods, it might be that prices of imported inputs did not fully adjust as well, which provides another motivation for this study and a reason to also investigate the "recent strong Franc" period separately.

Despite their shortcomings, using unit values as proxies for prices is common in the ERPT literature because of their wide availability. Compared to most studies, unit values in this paper are relatively more accurate reflections of prices as they are calculated quarterly at a highly disaggregated level and are trading partner-specific. This reduces the effect of changes in product quality or composition on estimates that can occur even within 8-digit product categories. ${ }^{1}$

1 The use of higher frequency data to calculate unit values for the regression analysis is an advantage over the yearly data employed by Амiтi, Iтsкнокі and Konings (2012) and Berman, Martin and Mayer (2012). Specifically, the estimates are less affected by quality 
Furthermore, unit values allow us to discriminate between intermediate and consumer goods, allowing us to construct industry-level imported input weighted exchange rate indices. ${ }^{2}$

The paper proceeds as follows. Section 2 provides a brief review of the relevant literature. Section 3 introduces the theoretical framework which forms the basis for the empirical set up in Section 5. Section 4 presents the data and describes the construction of the imported input weighted exchange rate. Section 6 describes the results from estimation and Section 7 concludes.

\section{Related Literature}

This section highlights results and empirical issues from previous work closely related to our paper. A complete overview of the extensive pass-through literature is beyond the scope of this brief review (for more extensive literature reviews see Burstein and Gopinath, 2013; Goldberg and Knetter, 1997; and GreenaWAy, KNELLER and Zhang, 2010).

In a contemporaneous study, Amiтi, Iтskнoкi and Konings (2012) investigate ERPT into export prices considering firms' import intensities and destination market shares. They show that firms employing a higher share of imported inputs and with larger market shares in export markets have lower ERPT. In contrast, we emphasise the use of imported inputs as a mechanism to keep profit margins stable in periods of exchange rate volatility. Although they also provide evidence for the exchange rate sensitivity of input prices at the firm-level, using higher frequency data we estimate sectoral pass-through rates into imported input prices in an empirical framework that controls more carefully for changes in countryspecific economic conditions and product-driven differences in marginal costs.

Athukorala and Menon (1994) examine the pricing behaviour of Japanese exporters by taking into account the aggregate changes of intermediate costs arising from exchange rate movements. Similar to Амiтı, Iтsкнокі and Konings (2012), their investigation of quarterly export prices reveals that if the cost-saving effect of exchange rate appreciations is considered the pass-through rate into foreign currency prices for total manufacturing exports declines from 0.78 to 0.67 .

and compositional changes due to higher time series variation within a given time period and, additionally, the time series properties can be tested. On the other hand, one shortcoming of our data is that we cannot control for firm characteristics, unlike in these studies.

2 Unfortunately, imported input prices at the industry-level cannot be constructed with the price data from the Swiss statistical agency (BFS). 
Their results also reveal a high sectoral heterogeneity in ERPT, which indicates that sectoral estimations should be performed. ${ }^{3}$ In this paper, we go a step further by investigating average ERPT into export prices for 15 goods sectors using price data (unit values) at a highly disaggregated and bilateral level. Moreover, we explicitly include disaggregated proxies of imported input prices faced by exporting industries in each period. Finally, we also estimate how these intermediate import prices react to exchange rate changes (again using highly disaggregated data) to investigate whether "natural hedging" is effective.

In another study using a panel of French firms, Berman, Martin and Mayer (2012) find a positive "cost adjustment effect" (positive coefficient on the interaction between the real exchange rate and firm intermediate imports over sales) on producer currency export prices, and thus - in line with Amiтi et al. (2013) and Athukorala and Menon (1994) - smaller ERPT into foreign currency prices when taking input cost changes into account. Thus, the estimations in all three studies imply that exchange rate driven cost fluctuations are incompletely passed on to foreign consumers. Consequently, the remaining input cost variation is used to cushion movements in the exporters' profit margins. We are the first to investigate this issue in more detail. Relatedly, Greenaway, Kneller and ZHANG (2010) investigate a panel of UK manufacturing firms and suggest that the negative effect of an exchange rate appreciation on firm exports is lower in industries that import a greater share of inputs.

As indicated by Athukorala and Menon (1994) and Greenaway, KnelLER and ZHANG (2010), industry variation in the pass-through rates are likely to reflect differences in the cost structures across industries. Along the same line, Campa and Goldberg (1997) and Hummels, Ishir and Yi (2001) point to the increasingly important role of global supply chains, and accordingly to the share of imported inputs as an important determinant of industry cost structure. Acknowledging the cost contribution of imported inputs, we emphasise the cost sensitivity of imported inputs to exchange rate movements and its subsequent effect on export pricing. The sensitivity of prices at the importer side also influences ERPT at the exporter side, but this interconnection has surprisingly not received adequate attention in the empirical ERPT literature. Aksoy and RiYanto (2000) formalise this issue and show that ERPT in the downstream export market depends on the pricing behaviour of foreign upstream suppliers. Finally, Ihrig, Marazzi and Rothenberg (2006) argue that the decline

3 Separate estimations for seven manufacturing sub-industries suggest a substantial upward aggregation bias: at the disaggregated level, total ERPT ranges from 0.04 for textiles to 0.53 for transport equipment. All estimates are thus lower than 0.67 at the aggregated level. 
of pass-through rates into domestic prices experienced in all G-7 countries over the last two decades may also be a consequence of the steady rise of cross-border production arrangements.

In other relevant work, Goldberg and CAMpa (2010) calibrate a structural model of the consumer price index (CPI) sensitivity to exchange rates with data from 21 OECD countries. They find that the goods' cost shares of imported inputs are the dominant channel through which exchange rate shocks are transmitted into consumer prices. Gopinath and Rigobon (2008) and Gopinath, ITsкнокі and RigoвоN (2010) report low pass-through rates into US import border prices. As argued by Goldberg and Hellerstein (2008), this is strongly suggestive but not rigorous evidence that imported inputs invoiced in USD play an important role in the pricing of US import goods. CAMPA and GonZalez Minguez (2006) show that differences of ERPT into domestic prices in the euro area countries may be explained by the degree of openness to non-euro imports of each country. Campa and Goldberg (1995) and Campa and Goldberg (1999) provide evidence for the US, UK, Japan and Canada that suggests that sectoral investment rates respond to exchange rate fluctuations depending primarily on a sector's exposure to imported inputs and export markets. ${ }^{4}$ Yet the issue of how pricing on the export side is related to imported input costs remains unresolved in all the cited studies. Our study fills this gap in the pass-through literature by recognising explicitly in the empirical framework that the exporters' pricing decisions may have become inextricably intertwined with the pricing behaviour of foreign input suppliers.

4 Their empirical findings suggest that a depreciation of the domestic currency tends to reduce investments particularly in competitive sectors that employ a large fraction of imported inputs, whereas high mark-up sectors with lower imported input shares are less affected by exchange rates. A possible explanation is again that the sensitivity of imported input prices to exchange rates differs across sectors, probably reflecting distinct competitive environments. 


\section{Theoretical Framework}

\subsection{Import Price Equation}

We assume an exporting sector $s$ specific Cobb-Douglas production function with the share $\alpha_{s}$ corresponding to imported inputs and the share $1-\alpha_{s}$ to domestic inputs including labour services.

$$
Q_{s}=\left(K^{*}\right)^{\alpha_{s}}(K)^{1-\alpha_{s}}
$$

The marginal cost function dual to (1) is given by:

$$
\begin{aligned}
& M C_{s}\left(W, W^{*}(E, Z), \alpha_{s}, E\right)=A_{s} W^{1-\alpha_{s}}\left(E W^{*}(E, Z)\right)^{\alpha_{s}}, \\
& A_{s}=\alpha_{s}^{-\alpha_{s}}\left(1-\alpha_{s}\right)^{\alpha_{s}-1},
\end{aligned}
$$

where $W$ is the price of domestic inputs, $W^{*}$ denotes the price of imported inputs denominated in the foreign currency and $E$ is the bilateral exchange rate between Switzerland and the import source country defined as CHF per unit of the foreign currency. $Z$ includes all factors that affect the foreign currency price of imported inputs $W^{*}$, such as the state of the business cycle or increases in producer prices due to changes in foreign wages or commodity prices. ${ }^{5}$ Taking logs and totally differentiating (2) leads to the following expression:

$$
\tilde{M} C_{s}=\tilde{A}+\left(1-\alpha_{s}\right) \widetilde{W}+\alpha_{s}\left(\tilde{E}+\frac{\partial w^{*}}{\partial W^{*}} \frac{\partial W^{*}}{\partial e} \tilde{E}+\frac{\partial w^{*}}{\partial W^{*}} \frac{\partial W^{*}}{\partial z} \tilde{Z}\right)
$$

where a " $\sim$ " over a variable denotes percentage changes and small letters denote the log of the variables. It is clear from (3) that a higher share of imported inputs, $\alpha$, results in a higher sensitivity of marginal costs to exchange rate fluctuations. Price changes of imported inputs in CHF can be decomposed into the direct

5 To keep the derivation of the pricing formula as simple as possible, as in CAMPA and GoldBERG (1995), we assumed that domestic input prices are not affected by exchange rates. Taking into account the possible price adjustments of domestic suppliers to exchange rate movements would increase the effect of exchange rates on marginal costs. For instance, an appreciation of the CHF is likely to result in a reduction of domestic input prices to stay competitive. 
effect $\widetilde{E}$ on the Swiss price of imported inputs and the indirect consequence of an exchange rate change on the pricing behaviour of foreign suppliers,

$$
\tilde{W}^{*}=\frac{\partial w^{*}}{\partial W^{*}} \frac{\partial W^{*}}{\partial e} \tilde{E}
$$

Moreover, there are also third factors $\tilde{Z}$ such as wage increases (see above) affecting the costs of imported inputs. An interesting limiting case is local currency pricing (LCP) which combined with sticky prices in the short-run implies that the pass-through rate is zero or formally:

$$
\widetilde{E}+\frac{\partial w^{*}}{\partial W^{*}} \frac{\partial W^{*}}{\partial e} \tilde{E}=0
$$

The price reducing effect of an appreciation is here completely offset by the price increases of the foreign suppliers. More generally, percentage changes of imported input prices in CHF of intermediate goods sourced from foreign supplier $i, \tilde{P}_{s, i}^{m}$, due to exchange rates movements, which corresponds to the first term in brackets in (3), can be defined as follows:

$$
\tilde{P}_{s, i}^{m}=\left(1+\frac{\partial w^{*}}{\partial e}\right) \tilde{E}
$$

Thus the effect of a percentage change in the bilateral exchange rate $\tilde{E}$ depends on the elasticity of the foreign currency input prices to exchange rates or equivalently on the elasticity of mark-ups to exchange rates, $\partial w^{*} / \partial e$. If this elasticity equals zero, we obtain full pass-through. Conversely, if foreign suppliers adjust foreign prices and mark-ups when the exchange rate fluctuates, pass-through will be less than complete, $\partial w^{*} / \partial e<0$, or amplified, $\partial w^{*} / \partial e>0$. We test whether imported input prices of intermediate goods stemming from supplier country $i$ react to exchange rate changes as stated in equation (5). In line with equation (5), the simplified empirical equation takes the following logarithmic specification using first-differences and adding quarterly time dummies $t$ and time phases $p$ including four quarters (details in Section 5.1):

$$
d p_{t, i, s}^{m}=\theta_{p, i}+\lambda_{s}+\beta_{s} d e_{t}+\varepsilon_{t, i, s}
$$

where $d$ is the first-difference operator, $\beta_{s}$ corresponds to the sector-specific passthrough coefficient. $\beta_{s}=1$ would mean that this sector is characterised by full 
pass-through as a result of producer currency pricing (PCP) with sticky prices. In contrast, $\beta=0$ indicates zero pass-through. This would be a consequence of LCP of foreign input suppliers in the Swiss market as illustrated in equation (4). ${ }^{6}$

In the intermediate case, $\beta_{s}<1$, we have incomplete pass-through, which suggests that foreign input suppliers raise their prices and mark-ups when the CHF appreciates. KNETTER (1989) points out that this occurs when foreign input suppliers' perceived elasticity of demand rises with the local price (CHF). Then, a depreciation of the supplier's currency, $\tilde{E}<0$, induces foreign suppliers to increase their profit margins. This relationship would be reflected in the negative elasticity between the foreign input price and the exchange rate in equation (5), $\partial w^{*} / \partial e<0$. Conversely, a $\beta_{s}>1$ shows that exchange rate changes are transmitted into imported input prices in an amplified manner. This could indicate that the foreign input suppliers' demand elasticity may fall with the Swiss price of foreign inputs resulting in $\partial w^{*} / \partial e>0$. Full pass-through, $\partial w^{*} / \partial e=0$, indicates that the perceived demand elasticity does not change with the local price.

A set of fixed effects $\theta_{p, i}+\lambda_{s}$ in (6) captures changes in foreign input prices in a specific sector $s$ and over a time phase $p$ that can be attributed to changes in the economic conditions, the production costs $(\tilde{Z}$ in (3)) in the exporting country $i$, demand conditions in the importing country or changes in commodity prices.

\subsection{Export Price Equation}

In an imperfectly competitive environment such as the popular monopolistic competition framework, economic agents are price setters and their first order conditions from profit maximisation can be stated in the following way:

$$
P_{j, s}^{e}=M K_{j, s}\left(\frac{P_{j s}^{*}}{P_{j}^{*}}, Z_{j}, M C_{s}\left(E, W, W^{*}\right)\right) M C_{s}\left(E, W, W^{*}\right), P_{j, s}^{*}=\frac{P_{j, s}^{e}}{E},
$$

where $P_{j, s}^{e}$ is the FOB average export price in CHF of sector $s$ delivering to country $j, P_{j, s}^{*}$ is the corresponding price in local currency, $M C_{s}$ denotes the sector-specific marginal cost [see also equations (2) and (3)] and $M K_{j, s}$ represents the sector-destination specific mark-ups. Taking logs and totally differentiating (7) with respect to the bilateral exchange rate in terms of CHF per unit of the destination currency

6 All exchange rate movements are fully absorbed in the mark-ups of foreign suppliers in this case.

7 This would be the case with a constant elasticity of substitution (CES) demand function. 
$E$, the destination price index $P_{j}^{*}$, the demand-shifter $Z_{j}$ and the domestic and foreign input prices $W$ and $W^{*}$ we obtain the following term by solving for $\tilde{P}_{j, s}^{e}:^{8}$

$$
\begin{aligned}
\tilde{P}_{j, s}^{e} & =\frac{1}{\Gamma_{j, s}}\left[\left(\frac{\partial m k_{j, s}}{\partial P_{j, s}^{*}} \frac{\partial P_{j, s}^{*}}{\partial e}\right) \tilde{E}+\left(\frac{\partial m k_{j, s}}{\partial M C_{s}} \frac{\partial M C_{s}}{\partial e}+\frac{\partial m c_{s}}{\partial e}\right) \tilde{E}+\frac{\partial m k_{j, s}}{\partial z_{j}} \tilde{Z}_{j}\right] \\
& +\frac{1}{\Gamma_{j, s}}\left[\left(\frac{\partial m k_{j, s}}{\partial m c_{s}}+1\right)\left(\frac{\partial m c_{s}}{\partial w} \cdot \tilde{W}+\frac{\partial m c_{s}}{\partial w^{*}} \cdot \tilde{W}^{*}\right)+\frac{\partial m k_{j, s}}{\partial p_{j}^{*}} \tilde{P}_{j}^{*}\right]
\end{aligned}
$$

where

$$
\Gamma_{j, s}=1-\frac{\partial m k_{j, s}}{\partial p_{j, s}^{e}}
$$

which connects the reaction of the export price in CHF $\tilde{P}_{j, s}^{e}$ to the mark-up function. The exporter's price equations (7) and (8) show that the variable mark-up is a function of the ratio between the price of the Swiss export good in local currency, $P_{j, s}^{*}$, divided by an average price index, $P_{j}^{*}$, that encompasses close substitutes available in market $j$. A negative reduced-form relationship between mark-up and relative price (or, equivalently, incomplete ERPT), $\partial m k_{j, s} / \partial\left(P_{j, s}^{*} P_{J}^{*}\right)<0$, can arise not only in the monopolistic competition framework but is common to many models of international pricing (BURSTeIN and Gopinath, 2013). ${ }^{9}$ and 10 More generally, the export price reaction to exchange rate changes depends on the reaction of the mark-ups to currency movements,

$$
\frac{1}{\Gamma_{j, s}} \frac{\partial m k_{j, s}}{\partial P_{j, s}^{*}} \frac{\partial P_{j, s}^{*}}{\partial e} .
$$

8 The following derivative signs, $\partial m k_{j, s} / \partial m c_{s} \leq 0, \partial m k_{j, s} / \partial p_{j}{ }^{*} \geq 0, \partial m k_{j, s} / \partial z_{j} \geq 0$, hold without equality in models that lead to demand functions that face an increasing demand elasticity with the local price, while they hold with equality in the constant elasticity of substitution (CES) case (see also the text below equation (8)). $\partial m c_{s} / \partial e \geq 0$, stems from equation (3), $\partial m c_{s} / \partial w>0, \partial m c_{s} / \partial w^{*}>0$ denote that increasing input prices result in higher marginal costs.

9 See for instance Corsetti and Dedola (2005) and Atreson and Burstein (2008).

10 In the uninteresting limiting case of a constant elasticity of substitution (CES) demand function the mark-up is constant and thus the following derivative $\partial m k_{j, s} / \partial\left(P_{j s}^{*} P_{J}^{*}\right)=0$ holds. 
As on the import side, this elasticity depends on how exporters perceive the demand schedule in a specific export market. For instance, a positive relationship between a CHF depreciation and the mark-up,

$$
\frac{1}{\Gamma_{j, s}} \frac{\partial m k_{j, s}}{\partial P_{j, s}^{*}} \frac{\partial P_{j, s}^{*}}{\partial e}>0,
$$

holds whenever a firm is confronted with a residual demand that exhibits an increasing elasticity with the local price - this is the case for demand functions that are less convex than in the constant elasticity of substitution (CES) case irrespective of the form of imperfect competition as highlighted by KNETTER (1989) and illustrated by Yang (1997) and Dornbusch (1987) for extended Dixit-Stiglitz and Cournot frameworks. ${ }^{11}$ and 12 With such a perceived demand function, exporters that face an appreciated currency, $\tilde{E}<0$, try to remain competitive by reducing mark-ups. A mark-up elasticity of one,

$$
\frac{1}{\Gamma_{j, s}} \frac{\partial m k_{j, s}}{\partial P_{j, s}^{*}} \frac{\partial P_{j, s}^{*}}{\partial e}=1,
$$

corresponding to zero ERPT, means that the mark-up fully absorbs exchange rate movements. If the demand curve is more convex than in the CES case, it could occur that exporters increase the mark-up when the exporter's currency appreciates leading to an overreaction of local prices to exchange rate changes.

The second term in (8) illustrates the effect of exchange rate changes on marginal costs and mark-ups working through imported input prices. ${ }^{13}$ Contingent on the imported input price reactions [see equations (5) and (6)], exporters may

11 In the extended Dixit-Stiglitz framework of YANG (1997) based on Dornbusch (1987), firms take into account their non-negligible effect of quantity decisions on the aggregate industry price index. AtKeson and Burstein (2008) show that the endogenous mark-up in our sense, $\partial m k_{j, s} / \partial e>0$, that leads to incomplete pass-through can be even introduced in a CESframework with small modifications.

12 Our derivation of the exporter's pricing and pass-through in equations (7) and (8) is therefore not limited to monopolistic competition frameworks but holds more generally as well.

13 Please note that the bilateral exchange rate variable, $\tilde{E}$, in the first and second term of equation (8) can differ according to the origins of the imported inputs used and the specific destination of an export good. 
benefit from lower marginal costs through cheaper foreign inputs when their currency appreciates, $\partial m c_{s} / \partial e \geq 0$, and may also increase profit margins,

$$
\frac{\partial m k_{j, s}}{\partial M C_{s}} \frac{\partial M C_{s}}{\partial e} \leq 0 .
$$

The mark-up adjustment depends again on the perceived demand elasticity. Furthermore, as in Melitz and Ottaviano (2008), more competitive export markets are characterised by lower local prices, $P_{j}$, for similar goods, and thus higher demand elasticities which force exporters to reduce export prices, $\partial m k_{j, s} / \partial p_{j}^{*}>0$. From (8) one can also note that controlling for differences in marginal costs, preferably at the product level, is important due to their direct impact on export prices and through their effect on the price-cost margins since sectors with lower marginal costs $M C_{s}$ are able to set higher mark-ups, $\partial m k_{j, s} / \partial m c_{s} \leq 0 .{ }^{14} Z_{j}$ is a demand shifter related to destination-specific preferences for a good but also on general economic conditions in market $j$. Stronger preferences and better conditions both increase the exporters' ability to raise export prices and margins, $\partial m k_{j, s} / \partial z_{j}>0$.

Equation (8) leads us directly to our simplified empirical specification (details in Section 5.2):

$$
d p_{t, j, s}^{e}=\theta_{p, j}+\eta_{s}+\gamma_{1} * d e_{t}+\gamma_{2} * d e_{t, s}^{m}+\varepsilon_{t, j, s}
$$

where $\gamma_{1}$ denotes the pricing-to-market (PTM) coefficient and corresponds to the mark-up elasticity to exchange rates in equation (8),

$$
\gamma_{1}=\frac{1}{\Gamma_{j, s}} \frac{\partial m k_{j, s}}{\partial P_{j, s}^{*}} \frac{\partial P_{j, s}^{*}}{\partial e} .
$$

A PTM coefficient equalling one, $\gamma_{1}=1$, represents an implication of LCP in the sense that export prices in CHF and mark-ups move one-to-one with exchange rates. As a consequence, a CHF appreciation erodes profit margins. ERPT into local prices (in foreign currency units or FCU) would then be zero. More specifically, the ERPT (in local/foreign prices) is calculated as $1-\gamma_{1}$, and therefore

14 This holds again for demand curves that are less convex than in the CES case (i.e. elasticity increases with price). 
is negatively related to PTM behaviour. $\gamma_{2}$ corresponds to the cost-adjustment coefficient and shows how export prices change when imported input prices change due to movements of exchange rates. As a result, it should be clear that not accounting for the cost-effect of exchange rate movements on the prices of imported inputs may create a bias in the pass-through estimations on the export side - as also argued by Goldberg and KNetTer (1997). The remaining variables affecting export prices as emphasised in equation (8) are captured by a set of fixed effects $\theta_{p, j}+\eta_{s}$ to account for changes in marginal costs, demand conditions at destination and product-specific differences of competitive pressure, preferences and production costs.

\section{Data}

We use quarterly and bilateral trade data based on HS 8-digit products between Q4-04 and Q3-11 taken from the Swiss Federal Customs Administration. The dataset is reduced to the 37 most important trading partners for Switzerland (including the majority of OECD countries and the BRICS and covering more than $90 \%$ of Swiss international trade flows). ${ }^{15}$

To account for the sensitivity of imported input prices to exchange rates in our export price equation, time-varying sectoral imported input weighted exchange rates are calculated based on supplier-specific imported input values similarly to Greenaway, Kneller and Zhang (2010). ${ }^{16}$ These exchange rate indices are then re-weighted according to the import share of each input sector in the respective export sector. ${ }^{17}$

More formally, these imported input weighted exchange rates are constructed as follows:

15 The list of countries includes Australia, Austria, Belgium, Brazil, Canada, Chile, China, Czech Republic, Denmark, Finland, France, Germany, Greece, Hungary, Iceland, India, Ireland, Israel, Italy, Japan, Luxembourg, Mexico, Netherlands, New Zealand, Norway, Poland, Portugal, Russia, Slovak Republic, Slovenia, South Africa, South Korea, Spain, Sweden, Turkey, UK and USA.

16 The classification of inputs (or intermediates) used in this paper is available at: http://wits. worldbank.org/wits/data_details.html

17 The respective shares are calculated from the $2001 \mathrm{I}-\mathrm{O}$ table for Switzerland taken from OECD (2012). The sector classification used to calculate the indices corresponds to those used in Swiss I-O tables. Each I-O table sector consists of one up to five 2-digit ISIC product groups. 


$$
e_{t, s o}^{m}=\sum_{s i}\left\{\left[\sum_{i}\left(\left(W_{s i}^{i}\right)_{t} *\left(\frac{e_{i, t}}{e_{i, o}}\right)\right)\right]_{t, s i} *\left(R_{s o}^{s i}\right)\right\},
$$

where $t$ is the time period, $i$ is the source country of imports, si is the input-output (I-O) imported input sector and so is the $\mathrm{I}-\mathrm{O}$ output sector. $e_{i t}$ and $e_{i o}$ are the supplier-specific bilateral nominal exchange rates in time $t$ and in the base period (fourth quarter 2004). ${ }^{18}\left(W_{s i}^{i}\right)_{t}$ is the value of imported inputs (CHF expenses) from source country $i$ relative to the total value of imported inputs in sector si during period $t$. This term is included to obtain an average imported input weighted exchange rate for each input sector si. Ultimately, these exchange rates are multiplied by $R_{s o}^{s i}$, corresponding to the share of imported inputs from sector $s i$ to total imported inputs in output/export sector so. The weights $R_{s o}^{s i}$ do not vary over time so that the index reflects primarily changes in the bilateral exchange rates. ${ }^{19}$ On the one hand, exchange rate movements affect the prices of imported inputs from a given origin. In addition, equation (10) also captures changing import patterns across countries over time through $\left(W_{s i}^{i}\right)_{t}$ that are also related to exchange rate changes. Thus, $e_{t, s o}^{m}$ is the imported input weighted exchange rate faced by each (output) sector so in each period $t$.

On the import side (Table 1), the dependent variable is constructed as the first-difference of log imported input unit values at the HS 8-digit level. The main independent variable is constructed as the first-difference of log nominal exchange rates. Similarly, on the export side (Table 2), the dependent variable corresponds to the first-difference of log export product unit values $(\mathrm{CHF} / \mathrm{kg})$ and the exchange rate variable is constructed in the same way as on the import side. The additional control on the export side is the log change of sectoral imported input exchange rate indices that are faced by exporters in each sector, $d e_{t, s^{*}}^{m}$ Thus, the variables of interest, being the first-differences of logs, correspond to growth rates of the underlying level variables. The dependent variables in both datasets are on average (almost) zero in each sector. The growth rates of exchange rates have naturally no variation across sectors and are also zero on average. The exchange rate indices of imported inputs are weighted averages at the sectoral level (that is, they vary only across time and not across products within sectors).

18 Therefore, $e_{i, t} / e_{i, o}$ corresponds to an exchange rate index.

$19 R_{s o}^{s i}$ is based on the $2001 \mathrm{I}-\mathrm{O}$ table for Switzerland taken from OECD (2012). From the OECD, an I-O table for 2005 is also available. Comparisons of Swiss I-O tables between 2001 and 2005 show that the sectoral import shares in total imports in an output sector in fact remain relatively stable over time and are likely to be driven by sector-specific technological factors. 
Table 1: Descriptive Statistics: Import Price Equation

\begin{tabular}{|lcccc}
\hline \multicolumn{1}{l}{ Imported input price } & Mean & Std. Dev. & Min. & Max. \\
\hline Dependent variable: & & & & \\
1 Agriculture (3'378) & -0.00 & 0.62 & -3.97 & 3.83 \\
2 Mining \& quarrying (279) & -0.02 & 1.51 & -5.15 & 6.09 \\
\hline 3 Food \& beverages (17'918) & -0.00 & 0.60 & -6.10 & 6.08 \\
\hline 4 Textiles (53'111) & -0.00 & 0.74 & -5.51 & 6.63 \\
\hline 5 Wood products (4'572) & 0.01 & 0.74 & -4.52 & 5.41 \\
\hline 6 Paper products (16'495) & 0.00 & 0.78 & -6.25 & 6.78 \\
\hline 7 Chemicals \& pharmaceuticals (104'450) & -0.00 & 1.19 & -11.77 & 10.33 \\
\hline 8 Rubber \& plastics products (13'408) & -0.00 & 0.88 & -7.36 & 6.75 \\
\hline 9 Mineral products (6'895) & -0.00 & 1.03 & -7.04 & 6.31 \\
\hline 10 Iron \& steel (50'285) & 0.00 & 0.81 & -8.78 & 8.44 \\
\hline 11 Fabricated metal products (16'567) & 0.00 & 0.97 & -7.42 & 8.16 \\
\hline 12 Machinery \& equipment (2'754) & -0.01 & 0.99 & -6.19 & 6.35 \\
\hline 13 Electrical machinery (3'634) & 0.00 & 0.99 & -5.00 & 5.74 \\
\hline 14 Communication equipment & - & - & - & - \\
\hline 15 Precision instruments (9'125) & 0.01 & 1.09 & -7.57 & 8.56 \\
\hline Independent variable: & & & & \\
\hline Nominal exchange rate & -0.01 & 0.03 & -0.24 & 0.19 \\
\hline
\end{tabular}

Notes: Figures in parentheses correspond to the number of observations in the respective sectors; reported statistics for the nominal exchange rate are provided for the dataset as a whole not for each sector separately; figures missing for input sector 14 as no hs 8 input product classified within sector 14 .

Table 2: Descriptive Statistics: Export Price Equation

\begin{tabular}{lcccc}
\hline \multicolumn{1}{c}{ Export product price } & Mean & Std. Dev. & Min. & Max. \\
\hline Dependent variable: & & & & \\
1 Agriculture (10'944) & 0.00 & 0.97 & -8.90 & 10.13 \\
2 Mining \& quarrying (9’403) & 0.00 & 1.14 & -10.95 & 10.83 \\
\hline Food \& beverages (73'240) & 0.00 & 0.57 & -7.58 & 8.17 \\
4 Textiles (185'355) & -0.00 & 0.84 & -8.51 & 9.35 \\
5 Wood products (10'457) & -0.01 & 0.95 & 7.11 & 8.11 \\
& & & & \\
\hline
\end{tabular}




\begin{tabular}{llrrr}
\hline Export product price & Mean & Std. Dev. & Min. & Max. \\
\hline 6 Paper products (47'404) & -0.00 & 0.98 & -11.42 & 8.80 \\
7 Chemicals \& pharmaceuticals (190'038) & 0.00 & 0.98 & -12.10 & 12.32 \\
\hline Rubber \& plastics products (58'638) & 0.00 & 0.90 & -9.29 & 10.24 \\
\hline Mineral products (36'427) & -0.00 & 1.07 & -9.93 & 9.82 \\
10 Iron \& steel (60'706) & 0.01 & 0.96 & -9.28 & 9.34 \\
11 Fabricated metal products (133'608) & 0.00 & 0.92 & -8.74 & 9.14 \\
12 Machinery \& equipment (209'033) & -0.00 & 1.00 & -10.91 & 11.87 \\
13 Electrical machinery (97'780) & -0.00 & 0.98 & -10.35 & 10.35 \\
14 Communication equipment (27'876) & 0.00 & 1.21 & -11.67 & 12.51 \\
\hline 15 Precision instruments (103'826) & 0.00 & 0.93 & -8.43 & 9.64 \\
\hline Independent variables: & & & & \\
$\quad$ Nominal exchange rate & -0.01 & 0.04 & -0.24 & 0.19 \\
\hline Import weighted nominal exchange rate & -0.01 & 0.02 & -0.10 & 0.06 \\
\hline
\end{tabular}

Notes: Figures in parentheses correspond to the number of observations in the respective sectors; reported statistics for the nominal exchange rate and the imported nominal exchange rate are provided for the dataset as a whole not for each sector separately.

The first column of Table 3 shows ratios of imported inputs relative to the sum of total inputs and total compensation to employees (or total production costs) while the second column shows ratios of imported inputs relative to total inputs. Data and the sector classification are taken from the 2001 I-O table for Switzerland published by the OECD (2012). As Table 3 highlights, imported inputs make up more than $10 \%$ of total production costs in all Swiss sectors and are particularly high in some manufacturing sectors (e.g. Textiles $27 \%$, or Electrical machinery 25\%). By construction, these figures are even higher when looking at the simple ratios of imported relative to total intermediate inputs (e.g. Textiles $38 \%$, or Electrical machinery 31\%). 
Table 3: Share of Imported Inputs of Total Production Costs in Switzerland by Sector

\begin{tabular}{|c|c|c|c|}
\hline & & $\begin{array}{c}\text { (Imported inputs) / } \\
\text { (Total inputs }+ \\
\text { Compensation } \\
\text { of employees) }\end{array}$ & $\begin{array}{c}\text { (Imported inputs)/ } \\
\text { (Total inputs) }\end{array}$ \\
\hline & Agriculture & 0.18 & 0.22 \\
\hline & Mining \& quarrying & 0.09 & 0.13 \\
\hline 3 & Food $\&$ beverages & 0.14 & 0.17 \\
\hline & Textiles & 0.27 & 0.38 \\
\hline & Wood products & 0.11 & 0.18 \\
\hline 6 & Paper products & 0.14 & 0.21 \\
\hline 7 & Chemicals \& pharmaceuticals & 0.24 & 0.29 \\
\hline 8 & Rubber \& plastics products & 0.19 & 0.27 \\
\hline 9 & Mineral products & 0.18 & 0.27 \\
\hline & Iron $\&$ steel & 0.25 & 0.35 \\
\hline & Fabricated metal products & 0.21 & 0.35 \\
\hline & Machinery \& equipment & 0.17 & 0.25 \\
\hline & Electrical machinery & 0.25 & 0.31 \\
\hline & Communication equipment & 0.21 & 0.32 \\
\hline & Precision instruments & 0.16 & 0.22 \\
\hline
\end{tabular}

Source: OECD (2012)

\section{Empirical Strategy and Econometric Issues}

Our theoretical derivations in Section 3 directly lead to estimations in first differences in line with equations (6) and (9). To emphasise the need for estimations in first differences not only from a theoretical but also from an econometric point of view, we performed panel unit root tests on our import and export price as well as exchange rate series. Taking account of cross-sectional dependence (particularly important in our exchange rate series) and seasonalities (particularly important in our price series), we could not decisively reject the null of unit roots and thus the non-stationarity of our time series, especially on exchange rates. ${ }^{20}$ The results from these tests thus provide a further justification for an estimation in first-differences.

20 These results are available upon request. 


\subsection{ERPT into Imported Input Prices}

The empirical equation (6) for ERPT into imported input prices is estimated for each I-O input sector $s i$ separately. The HS 8 -digit input product dimension $k$ and partner country dimension $i$ are introduced and lagged exchange rate terms are added to allow for the possibility of gradual adjustment of these prices. Thus, we estimate sectoral regressions based on bilateral import data at the HS 8-digit level for each I-O input sector level $s i$, as follows:

$$
d p_{t, i, k}^{m}=\theta_{p, i}+\lambda_{b s 6}+\sum_{t=0}^{-2}\left(\beta_{t} * d e_{t, i}\right)+u_{t, i, k},
$$

where the index si is omitted, $d$ is the first-difference operator, $t$ is the time component defined as one quarter, $p$ is time phase including four quarters (Q4 of one year to Q3 of the next year), $i$ is the foreign supplier and $k$ refers to the intermediate product. Notations are consistent with those used in Section 3, where lower case letters designate logarithms. The average short-run relationship between exchange rates and the imported input prices in each $s i$ is given by the estimated coefficient $\beta_{0}$. The long-run elasticity is given by the sum of the coefficients on the contemporaneous exchange rate and two lags of exchange rate terms $\Sigma_{t=0}^{-2} \beta_{t} \cdot{ }^{21}$

Finally, the set of fixed effects $\theta_{p, i}+\lambda_{b s \sigma}$ captures all other factors affecting intermediate input prices. In particular, $\theta_{p, i}$ capture aggregate changes in production costs (including commodity price changes) in source country $i$ as well as the evolution of demand conditions in the importing country, Switzerland. It is therefore assumed that the time- and supplier-varying fixed effects are homogeneous across all $h s 8$ products of a given $s i$ sector, so that the $k$ dimension can be neglected. Marginal costs and demand conditions are difficult to measure especially at the product level. As a remedy, other researchers have used aggregate measures such as consumer-price-, producer-price- or labour-cost-indices as marginal cost proxies and GDP as proxies for demand conditions (see for example Campa and Goldberg, 2005, or Auer and Chaney, 2009). Given that our data includes the product dimension, we add fixed effects for each HS 6-digit product group, $\lambda_{b s 6}$, to control for time and supplier invariant determinants of price adjustments within a $h s 6$ product group.

21 Variable deletion F-tests confirmed that high sectoral long-run pass-through rates are mostly achieved within three quarters. In the benchmark specifications, we thus only used two lags for the long-run analysis. 
In order to see to what extent I-O output sectors so face imported input price adjustments when exchange rates change, the estimated short- and long-run ERPT effects on imported input prices have to be re-weighted according to each $s i$ 's share of each so's total imported inputs. These shares are calculated from the I-O table 2001 for Switzerland and are denoted as $R_{s o}^{s i}$, where $\sum_{s i}\left(R_{s o}^{s i}\right)=1$ is equal to 1 in all so sectors. Average short-run ERPT effects on imported input prices per I-O output sector $s o$ are thus given as follows:

$$
\beta_{0}^{s o}=\sum_{s i}\left(R_{s o}^{s i} * \beta_{0}^{s i}\right)
$$

and the long-run effects as follows:

$$
\sum_{t=0}^{-2} \beta_{t}^{s o}=\sum_{s i}\left(R_{s i}^{s i} * \sum_{t=0}^{-2} \beta_{t}^{s i}\right)
$$

After estimating (11), we calculated the standard errors of the linear combinations (12) and (13) that take into account the variance-covariance structure of the estimated coefficients $\beta_{t}^{s i}$.

\subsection{ERPT into Export Prices}

Our export regressions estimate ERPT on export prices in line with our theoretical considerations and equation (9). Similar to the estimation strategy on the import side, first-difference equations, based on bilateral export data at the HS8digit level with lagged exchange rate terms to allow for the possibility of gradual adjustment of export prices, are estimated separately for each I-O output sector level $s o$, as follows:

$$
d p_{t, j, f}^{e}=\theta_{p, j}+\lambda_{b s 6}+\sum_{t=0}^{-2}\left(\gamma_{1, t} * d e_{t, j}\right)+\sum_{t=0}^{-2}\left(\gamma_{2, t} * d e_{t}^{m}\right)+v_{t, j, f},
$$

where index $j$ stands for export destination, $f$ for export product at the $h s 8$ level and $s o$ is omitted. ${ }^{22}$ Letters or expressions already used in equation (9) have the same interpretation; lower case letters designate logarithms. The fixed effects $\theta_{p, j}$

22 Note that $f=k$ if the input $k$ is exported by Swiss exporters and $j=i$ if source country $i$ is also a destination country for Swiss exports. 
control for phase and destination dependent demand shifts, for instance, due to changes in general economic conditions. As in the import side equation (11), these fixed effects absorb all relative cost and demand changes between Switzerland and one specific destination country. ${ }^{23}$ Fixed effects $\lambda_{b s 6}$ capture variations in domestic marginal costs for different export products at the $h s 6$-level.

Short-run total exchange rate pass-through, TPT, (on foreign currency export prices) per $s o$ is in line with our theoretical framework defined as:

$$
1-\left(\gamma_{1,0}^{s o}+\gamma_{2,0}^{s o}\right)
$$

and for the long-run it is defined as:

$$
1-\sum_{t=0}^{-2}\left(\gamma_{1, t}^{s o}+\gamma_{2, t}^{s o}\right)
$$

where the first terms within the brackets in (15) and (16) correspond to mark-up adjustments due to exchange rate changes, or PTM effects. The second terms show the exchange rate driven cost-adjustment effects (CAE) through imported inputs. $^{24}$

23 As an example, if domestic sourcing becomes more expensive for whatever reason (e.g. domestic agricultural intermediates get more expensive for the food sector), this changes the relative demand and cost conditions for Swiss exporters vs. foreign producers and are hence captured by the $\theta_{p, j}$ dummies. In robustness checks, we also estimated models with (non-time varying) destination country dummies but time-varying product dummies instead. The ERPT coefficients turned out to be similar.

24 It should be noted that the theoretically derived CAE term is defined as follows: $\gamma_{2, t}^{s o} * \beta_{t}^{s o}$. These beta and gamma coefficients are however estimated in two different samples, the imported input price sample and the export price sample. As a result, obtaining the appropriate standard errors for these estimates (i.e. the product of the estimates) is a non-trivial task and cannot be accomplished with conventional bootstrapping methods. One possible remedy is to construct firstly all variables needed for the import regression within the export price sample, which does however substantially reduce variation in the data. Secondly, the new import regression and the export regression is estimated through seemingly unrelated equations (SUR) in order to apply new post-estimation simulations to calculate non-linear combinations and their standard errors. We estimated such models and came to the same conclusions as with the simpler and straightforward approach described in the main text. Not least, estimates from the two alternatives do not substantially differ as the $\gamma_{2, t}^{s o}$ coefficients are not significantly different from zero for most sectors and/or the magnitude is close to zero. The combined effects $\gamma_{2, t}^{s o} * \beta_{t}^{s o}$ are thus also close to zero. We are grateful to Giovanni Mellace for important suggestions on these issues. 


\section{Results}

Table 4 presents sectoral ERPT coefficients for imported input prices. The first two columns display average short- and long-run elasticities in each input sector, while the last two columns report the responses of imported input prices faced by each output/export sector. The latter figures are calculated as weighted averages of pass-through coefficients across input sectors according to their import weight in a respective output sector [see equations (12) and (13)]. To account for possible autocorrelation in the errors within trading partner countries, we report robust-clustered standard errors using the partner country as the clustering unit because nominal exchange rates are country-pair-specific and not product-specific. ${ }^{25}$ This strategy is followed in all regressions reported in this paper. In addition, we use weighted least squares in the import and export equation in order to give a higher weight to price adjustments of imported/exported products from or to a given country with higher trade values.

Looking first at the results in column 1 and 2, there is some sectoral heterogeneity in the short-run, but the estimated long-run coefficients are not statistically significantly different from one in 8 out of 14 sectors, but significantly positive, and statistically above one in 2 sectors. ${ }^{26}$ With regard to imported input prices faced by each output sector in the third and fourth column, the picture remains unchanged with complete pass-through or exchange rate amplification (coefficients above one) being the appropriate characterisation of the input price reactions to exchange rate movements, especially in the long-run. ${ }^{27}$ With regard to the marginal cost channel, these high pass-through rates imply a substantial input cost sensitivity to exchange rate changes, which is a precondition for being a valid explanation for incomplete ERPT to export prices.

The magnitudes of the pass-through coefficients into Swiss imported input prices by input sector (first two columns) may be surprisingly high, but they are largely in line with the existing evidence. For instance, CAmpa and Goldberg (2005) estimate a long-run pass-through rate of 0.94 , which is not significantly

25 Unless the pricing of products differs greatly in terms of which currency it is denominated in, partner country is the preferred clustering unit. However, our results are robust to estimations using (partner country)*(hs8-product) as the clustering unit. These results are available upon request. We are grateful to Peter Egger for important suggestions on this issue.

26 Iron $\&$ steel and fabricated metal products.

27 For instance, a coefficient of 1.45 for the Textiles sector in the long-run (column 4 of Table 4) indicates that foreign suppliers increase CHF prices by about $14.5 \%$ when the CHF depreciates by $10 \%$. 
Table 4: ERPT into Imported Input Prices (in CHF)

\begin{tabular}{|c|c|c|c|c|c|}
\hline & & \multicolumn{2}{|c|}{ By input sector } & \multicolumn{2}{|c|}{ By output sector* } \\
\hline & & Short-run & Long-run & Short-run & Long-run \\
\hline & Agriculture & $\begin{array}{c}0.49 \\
(0.35)\end{array}$ & $\begin{array}{c}0.71 \\
(0.63)\end{array}$ & $\begin{array}{c}0.50^{\mathrm{a} / \mathrm{b}} \\
(0.20)\end{array}$ & $\begin{array}{c}1.34^{\mathrm{a}} \\
(0.51)\end{array}$ \\
\hline & Mining \& quarrying & $\begin{array}{c}2.78 \\
(3.78)\end{array}$ & $\begin{array}{c}6.54 \\
(4.04)\end{array}$ & $\begin{array}{c}1.09 \\
(1.05)\end{array}$ & $\begin{array}{c}3.09^{\mathrm{a}} \\
(1.21)\end{array}$ \\
\hline 3 & Food \& beverages & $\begin{array}{r}0.72^{\mathrm{a}} \\
(0.24)\end{array}$ & $\begin{array}{r}1.51^{\mathrm{a}} \\
(0.49)\end{array}$ & $\begin{array}{c}0.61^{\mathrm{a}} \\
(0.20)\end{array}$ & $\begin{array}{r}1.18^{\mathrm{a}} \\
(0.43)\end{array}$ \\
\hline 4 & Textiles & $\begin{array}{c}0.79^{\mathrm{a}} \\
(0.12)\end{array}$ & $\begin{array}{c}1.33^{\mathrm{a}} \\
(0.32)\end{array}$ & $\begin{array}{c}0.71^{a / b} \\
(0.12)\end{array}$ & $\begin{array}{c}1.45^{\mathrm{a}} \\
(0.38)\end{array}$ \\
\hline 5 & Wood products & $\begin{array}{c}1.13^{\mathrm{a}} \\
(0.20)\end{array}$ & $\begin{array}{c}1.71^{\mathrm{a}} \\
(0.37)\end{array}$ & $\begin{array}{r}0.97^{\mathrm{a}} \\
(0.15)\end{array}$ & $\begin{array}{c}1.79^{\mathrm{a}} \\
(0.40)\end{array}$ \\
\hline 6 & Paper products & $\begin{array}{l}0.58^{\mathrm{a} / \mathrm{b}} \\
(0.11)\end{array}$ & $\begin{array}{c}1.37^{\mathrm{a}} \\
(0.38)\end{array}$ & $\begin{array}{c}0.61^{\mathrm{a} / \mathrm{b}} \\
(0.15)\end{array}$ & $\begin{array}{c}1.60^{\mathrm{a}} \\
(0.41)\end{array}$ \\
\hline 7 & Chemicals \& pharmaceuticals & $\begin{array}{c}0.18^{b} \\
(0.45)\end{array}$ & $\begin{array}{c}1.79^{\mathrm{a}} \\
(0.81)\end{array}$ & $\begin{array}{c}0.75 \\
(0.72)\end{array}$ & $\begin{array}{l}2.65^{\mathrm{a} / \mathrm{b}} \\
(0.90)\end{array}$ \\
\hline 8 & Rubber \& plastics products & $\begin{array}{l}0.72^{\mathrm{a} / \mathrm{b}} \\
(0.11)\end{array}$ & $\begin{array}{c}1.56^{\mathrm{a}} \\
(0.32)\end{array}$ & $\begin{array}{c}0.34^{\mathrm{b}} \\
(0.33)\end{array}$ & $\begin{array}{c}1.81^{\mathrm{a}} \\
(0.68)\end{array}$ \\
\hline 9 & Mineral products & $\begin{array}{l}0.86^{\mathrm{a}} \\
(0.326)\end{array}$ & $\begin{array}{c}1.62^{\mathrm{a}} \\
(0.38)\end{array}$ & $\begin{array}{c}1.46 \\
(1.36)\end{array}$ & $\begin{array}{c}3.48^{\mathrm{a}} \\
(1.48)\end{array}$ \\
\hline 10 & Iron \& steel & $\begin{array}{c}1.12^{\mathrm{a}} \\
(0.28)\end{array}$ & $\begin{array}{l}2.32^{\mathrm{a} / \mathrm{b}} \\
(0.57)\end{array}$ & $\begin{array}{c}1.18^{\mathrm{a}} \\
(0.43)\end{array}$ & $\begin{array}{c}2.65^{\mathrm{a} / \mathrm{b}} \\
(0.63)\end{array}$ \\
\hline 11 & Fabricated metal products & $\begin{array}{l}0.73^{\mathrm{a} / \mathrm{b}} \\
(0.12)\end{array}$ & $\begin{array}{l}1.99^{\mathrm{a} / \mathrm{b}} \\
(0.45)\end{array}$ & $\begin{array}{c}1.03^{\mathrm{a}} \\
(0.22)\end{array}$ & $\begin{array}{l}2.27^{\text {a/b }} \\
(0.52)\end{array}$ \\
\hline 12 & Machinery \& equipment & $\begin{array}{c}0.55 \\
(0.98)\end{array}$ & $\begin{array}{c}1.85 \\
(1.13)\end{array}$ & $\begin{array}{c}0.68^{\mathrm{a}} \\
(0.30)\end{array}$ & $\begin{array}{l}1.88^{\mathrm{a} / \mathrm{b}} \\
(0.41)\end{array}$ \\
\hline 13 & Electrical machinery & $\begin{array}{c}0.30 \\
(0.49)\end{array}$ & $\begin{array}{l}1.59^{\mathrm{a}} \\
(0.44)\end{array}$ & $\begin{array}{c}0.61^{\mathrm{a}} \\
(0.24)\end{array}$ & $\begin{array}{l}1.84^{\mathrm{a} / \mathrm{b}} \\
(0.32)\end{array}$ \\
\hline 14 & Communication equipment & $\begin{array}{l}- \\
-\end{array}$ & - & $\begin{array}{c}0.73^{\mathrm{a}} \\
(0.15)\end{array}$ & $\begin{array}{l}1.89^{a / b} \\
(0.39)\end{array}$ \\
\hline 15 & Precision instruments & $\begin{array}{c}0.88^{\mathrm{a}} \\
(0.38)\end{array}$ & $\begin{array}{c}0.92 \\
(0.87)\end{array}$ & $\begin{array}{c}0.85^{\mathrm{a}} \\
(0.13)\end{array}$ & $\begin{array}{c}1.76^{\mathrm{a}} \\
(0.39)\end{array}$ \\
\hline
\end{tabular}

Notes: * Weighted average ERPT faced by each output sector (weights from I-O table); by input sector: short-run $=\beta_{0}^{s i}$, long-run $=\Sigma_{t=0}^{-2} \beta_{t}^{s i}$; by output sector: short-run $=\beta_{0}^{s o}$, longrun $=\Sigma_{t=0}^{-2} \beta_{t}^{s o} ;{ }^{a / b} \mathrm{H} 0$ of zero/full pass-through rejected at the 95\%-level; estimated with WLS (weight $=$ import value), robust-clustered standard errors in parentheses (cluster unit $=$ source country); phase-source varying fixed effects as well as hs 6 varying fixed effects; coefficients missing for input sector 14 as no hs 8 input product classified within sector 14 . 
different from one, for the Swiss manufacturing sector as a whole. GaUlier, LAHRÈCHE-RÉVIL and MÉJEAn (2008) estimate ERPT for each HS 4-digit product line separately and obtain an average ERPT of 0.7 for Switzerland. Only about $30 \%$ of their estimated pass-through coefficients are statistically different from one. For countries in the euro area, Campa and Gonzalez Minguez (2006) conclude that industry-specific pass-through rates into import prices are on the order of 0.8 and that many industries within a country reach full pass-through after only four months. Furthermore, Campa and Gonzalez Minguez (2006) show that pass-through into producer price indices is more than double the size of transmission into consumer prices suggesting higher pass-through into imported input goods compared to consumer goods. However, our results somewhat contradict some previous studies that estimate fairly low average ERPT into Swiss import price indices of around 0.3 to 0.4 (see SECO, 2011, Stulz, 2007, and Herger, 2012).

How can this high pass-through rate at the upper bound of prior estimates be explained? It is important to bear in mind that we only included input (intermediate) goods in the import regressions, while studies employing more aggregate price indices are likely to be biased towards consumer goods. In line with equation (5) in Section 3, high ERPT can be explained by an input demand elasticity that changes little with local prices (in CHF). This is reasonable for highly customised input goods tailored to specific needs of firms. Looking at long-run results by output sector (last column of Table 4), six sectors display ERPT rates larger than one. KNETTER (1989) documents this pricing behaviour for German and US exports. This indicates that demand elasticity may even increase with lower imported input prices for some output sectors. A possible explanation could be that at lower input prices, the demand composition may tilt toward more pricesensitive buyers. Although the next explanation is not specific to amplified ERPT $(>1)$, high ERPT could be a result of intrafirm import of inputs. Evidence shows that prices react stronger to exchange rates in intrafirm transactions and, consequently, in R\&D intensive sectors with higher shares of intrafirm trade such as chemicals or equipment goods (Antràs, 2011; Hellerstein and Villas-Boas, 2010; Neiman. 2010). ${ }^{28}$

Recent theoretical advances complement the imperfect competition model of mark-up pricing from Section 3 with distribution costs in the local market

28 This explanation is potentially highly relevant for the import regressions because intrafirm trade occurs mostly in input trade and is higher between countries with better institutions such as the rule of law (RANGAN, LAWRENCE and COOPER, 1993). For instance, the US share of intrafirm imports in total imports from Switzerland is about 60\% (ANTRÀs, 2011). 
in order to explain ERPT (see for example, Corsetti and Dedola, 2005, in a general-equilibrium framework or in Berman, Martin and Mayer, 2012, in a Melitz-type model). According to Goldberg and Campa (2010) and Berman, Martin and Mayer (2012), 30-60\% of local consumer goods prices are made up by distribution costs as opposed to a much lower distribution cost share for intermediate goods. This is important because a lower share of distribution costs incurred in local currency lowers the incentive for pricing-to-market (PTM), and thus increases pass-through rates in all models emphasising distribution costs. ${ }^{29}$ Our import side results support this class of models and suggest that prices of imported inputs faced by Swiss output/export industries are mainly invoiced in currencies of the foreign suppliers (PCP). As a consequence, Swiss industries benefit from exchange rate appreciations through cheaper imported inputs, in particular in those industries with a higher share of foreign inputs. ${ }^{30}$ In other words, high ERPT into imported input prices demonstrates that natural hedging in times of currency appreciations is effective. Moreover, variable deletion F-tests confirmed that these high sectoral long-run pass-through rates are mostly achieved within three quarters. ${ }^{31}$

As a robustness check, we performed the same estimations adding interaction terms for each exchange rate variable with a dummy that equals one for all observations during the "strong Franc" period (Q1 2010-Q3 2011, or since the nominal CHF/EUR exchange rate reached a level below 1.25 for the first time). This was done in order to study the pricing behaviour during this exceptional time. However, we could not find statistical evidence that the pricing strategies of foreign suppliers changed during the strong CHF period in the wake of the Eurozone crisis.

In addition, Table 8 in the Appendix reports results using a less restrictive specification that replaces the time phase $*$ source country dummies by hs2products $*$ source country varying fixed effects and time dummies. We have also added the first difference of log inflation in the source country as a control variable, while demand changes in Switzerland over time are absorbed in the time dummies. The results show that it takes a bit longer for ERPT to converge but it still occurs within three quarters as in the main specification. Otherwise, high

29 Previous empirical studies come to similar conclusions: Using French firm-level data, BERMAN, MARTIN and MAYER (2012) show that ERPT is substantially higher for intermediate goods than for consumer goods. Gaulier, Lahrèche-RÉvil and MÉJEAn (2006) reach the same conclusion using disaggregated trade data.

30 See also Аміті, Iтsкнокі and Konings (2012) for similar findings.

31 We also estimated equations with four lags which yielded similar results. 
Table 5: ERPT into Export Prices (in CHF and in Foreign Currency Units, FCU) Short-Run (with Import Weighted Exchange Rates)

\begin{tabular}{|c|c|c|c|c|c|c|}
\hline & \multicolumn{3}{|c|}{ In $\mathrm{CHF}$} & \multicolumn{2}{|c|}{ In FCU } \\
\hline & & $\begin{array}{l}\text { Direct } \\
\text { (PTM) }\end{array}$ & $\begin{array}{l}\text { Indirect } \\
\text { (CAE) }\end{array}$ & $\begin{array}{c}\text { Total } \\
(1-\mathrm{TPT})\end{array}$ & $\begin{array}{l}\text { Direct } \\
\text { (DPT) }\end{array}$ & $\begin{array}{c}\text { Total } \\
\text { (TPT) }\end{array}$ \\
\hline & Agriculture & $\begin{array}{c}0.21 \\
(1.34)\end{array}$ & $\begin{array}{c}0.47 \\
(1.28)\end{array}$ & $\begin{array}{c}0.69 \\
(0.36)\end{array}$ & $\begin{array}{c}0.79 \\
(1.34)\end{array}$ & $\begin{array}{c}0.32 \\
(0.36)\end{array}$ \\
\hline 2 & Mining \& quarrying & $\begin{array}{r}-0.02^{\mathrm{b}} \\
(0.13)\end{array}$ & $\begin{array}{l}2.78^{a / b} \\
(0.32)\end{array}$ & $\begin{array}{l}2.76^{a / b} \\
(0.29)\end{array}$ & $\begin{array}{r}1.02^{a} \\
(0.13)\end{array}$ & $\begin{array}{c}-1.76^{a / b} \\
(0.29)\end{array}$ \\
\hline 3 & Food $\&$ beverages & $\begin{array}{l}0.42^{a / b} \\
(0.14)\end{array}$ & $\begin{array}{r}-0.04^{b} \\
(0.15)\end{array}$ & $\begin{array}{l}0.38^{\mathrm{a} b \mathrm{~b}} \\
(0.13)\end{array}$ & $\begin{array}{l}0.58^{\mathrm{a} / \mathrm{b}} \\
(0.14)\end{array}$ & $\begin{array}{c}0.62^{a / b} \\
(0.13)\end{array}$ \\
\hline 4 & Textiles & $\begin{array}{r}0.75^{\mathrm{a}} \\
(0.24)\end{array}$ & $\begin{array}{c}-0.65^{a / b} \\
(0.30)\end{array}$ & $\begin{array}{r}0.10^{\mathrm{b}} \\
(0.17)\end{array}$ & $\begin{array}{r}0.25^{\mathrm{b}} \\
(0.24)\end{array}$ & $\begin{array}{r}0.90^{\mathrm{a}} \\
(0.17)\end{array}$ \\
\hline 5 & Wood products & $\begin{array}{c}0.52 \\
(0.29)\end{array}$ & $\begin{array}{r}0.94^{\mathrm{a}} \\
(0.37)\end{array}$ & $\begin{array}{l}1.46^{a / b} \\
(0.22)\end{array}$ & $\begin{array}{c}0.48 \\
(0.29)\end{array}$ & $\begin{array}{c}-0.46^{\mathrm{a} / \mathrm{b}} \\
(0.22)\end{array}$ \\
\hline 6 & Paper products & $\begin{array}{c}-0.04^{\mathrm{b}} \\
(0.31)\end{array}$ & $\begin{array}{c}0.11^{\mathrm{b}} \\
(0.46)\end{array}$ & $\begin{array}{c}0.07^{\mathrm{b}} \\
(0.20)\end{array}$ & $\begin{array}{c}1.04^{\mathrm{a}} \\
(0.31)\end{array}$ & $\begin{array}{c}0.93^{\mathrm{a}} \\
(0.20)\end{array}$ \\
\hline 7 & Chemicals \& pharmaceuticals & $\begin{array}{r}0.64^{\mathrm{a}} \\
(0.25)\end{array}$ & $\begin{array}{c}0.31 \\
(0.52)\end{array}$ & $\begin{array}{c}0.95 \\
(0.62)\end{array}$ & $\begin{array}{r}0.36^{\mathrm{b}} \\
(0.25)\end{array}$ & $\begin{array}{c}0.05 \\
(0.62)\end{array}$ \\
\hline 8 & Rubber \& plastics products & $\begin{array}{l}0.40^{\mathrm{a} / \mathrm{b}} \\
(0.19)\end{array}$ & $\begin{array}{c}0.41^{\mathrm{b}} \\
(0.24)\end{array}$ & $\begin{array}{r}0.81^{\mathrm{a}} \\
(0.11)\end{array}$ & $\begin{array}{l}0.60^{\mathrm{a} / \mathrm{b}} \\
(0.19)\end{array}$ & $\begin{array}{c}0.19^{\mathrm{b}} \\
(0.11)\end{array}$ \\
\hline 9 & Mineral products & $\begin{array}{c}0.62^{a / b} \\
(0.17)\end{array}$ & $\begin{array}{c}0.06^{\mathrm{b}} \\
(0.25)\end{array}$ & $\begin{array}{c}0.69^{a} \\
(0.24)\end{array}$ & $\begin{array}{c}0.38^{\mathrm{a} / \mathrm{b}} \\
(0.18)\end{array}$ & $\begin{array}{c}0.31^{\mathrm{b}} \\
(0.24)\end{array}$ \\
\hline 10 & Iron \& steel & $\begin{array}{r}-0.54^{\mathrm{b}} \\
(0.43)\end{array}$ & $\begin{array}{r}1.61^{\mathrm{a}} \\
(0.32)\end{array}$ & $\begin{array}{r}1.07^{\mathrm{a}} \\
(0.37)\end{array}$ & $\begin{array}{r}1.54^{\mathrm{a}} \\
(0.43)\end{array}$ & $\begin{array}{r}-0.07^{\mathrm{b}} \\
(0.37)\end{array}$ \\
\hline 11 & Fabricated metal products & $\begin{array}{r}0.25^{\mathrm{b}} \\
(0.16)\end{array}$ & $\begin{array}{r}0.32^{\mathrm{b}} \\
(0.21)\end{array}$ & $\begin{array}{l}0.57^{\mathrm{a} / \mathrm{b}} \\
(0.16)\end{array}$ & $\begin{array}{r}0.75^{a} \\
(0.16)\end{array}$ & $\begin{array}{c}0.43^{a / b} \\
(0.16)\end{array}$ \\
\hline 12 & Machinery \& equipment & $\begin{array}{c}0.26^{\mathrm{b}} \\
(0.24)\end{array}$ & $\begin{array}{c}-0.05^{\mathrm{b}} \\
(0.34)\end{array}$ & $\begin{array}{c}0.21^{\mathrm{b}} \\
(0.28)\end{array}$ & $\begin{array}{c}0.74^{\mathrm{a}} \\
(0.24)\end{array}$ & $\begin{array}{c}0.79^{\mathrm{a}} \\
(0.28)\end{array}$ \\
\hline 13 & Electrical machinery & $\begin{array}{l}0.51^{a / b} \\
(0.20)\end{array}$ & $\begin{array}{c}0.60 \\
(0.36)\end{array}$ & $\begin{array}{r}1.11^{\mathrm{a}} \\
(0.35)\end{array}$ & $\begin{array}{l}0.49^{a / b} \\
(0.20)\end{array}$ & $\begin{array}{r}-0.11^{\mathrm{b}} \\
(0.35)\end{array}$ \\
\hline 14 & Communication equipment & $\begin{array}{r}0.87^{\mathrm{a}} \\
(0.41)\end{array}$ & $\begin{array}{c}-0.24 \\
(0.71)\end{array}$ & $\begin{array}{c}0.64 \\
(0.71)\end{array}$ & $\begin{array}{c}0.13^{\mathrm{b}} \\
(0.41)\end{array}$ & $\begin{array}{c}0.36 \\
(0.71)\end{array}$ \\
\hline 15 & Precision instruments & $\begin{array}{r}0.20^{\mathrm{b}} \\
(0.15)\end{array}$ & $\begin{array}{r}-0.14^{\mathrm{b}} \\
(0.32)\end{array}$ & $\begin{array}{r}0.06^{\mathrm{b}} \\
(0.36)\end{array}$ & $\begin{array}{r}0.80^{a} \\
(0.15)\end{array}$ & $\begin{array}{r}0.94^{a} \\
(0.36)\end{array}$ \\
\hline
\end{tabular}

Notes: PTM (pricing to market coefficient),$=\gamma_{1,0}^{s o}$, CAE (cost-adjustment effect) $=\gamma_{2,0}^{s o}$, $1-\mathrm{TPT}=\gamma_{1,0}^{s o}+\gamma_{2,0}^{s o}, \mathrm{DPT}=1-\gamma_{1,0}^{s o}, \mathrm{TPT}$ (total pass-through coefficient $)=1-\left(\gamma_{1,0}^{s o}+\gamma_{2,0}^{s o}\right)$;

${ }^{a / b} \mathrm{H} 0$ of zero/one PTM, CAE or pass-through (DPT and TPT) rejected at the 95\%-level, respectively; estimated with weighted least squares (weight $=$ export value), robust-clustered standard errors in parentheses (cluster unit = partner country); phase-source varying fixed effects as well as $h s 6$ varying fixed effects. 
ERPT into imported input prices still prevails in the long-run, especially in the results by output sector (last column).

Table 5 displays the short-run PTM and pass-through coefficients as well as exchange rate driven cost-adjustment effects on pricing behaviour on the export side. We find substantial sectoral heterogeneity indicating - along the lines of KNETTER (1993) - that sectoral differences are important factors in explaining ERPT. The results for direct ERPT (DPT, column 4) show that 4 sectors out of 15 report partial ERPT, ${ }^{32} 6$ sectors are characterised by full pass-through ${ }^{33}$ and ERPT for 3 sectors is not statistically different from zero. ${ }^{34}$ The cost-adjustment effects denoted by Indirect (CAE) in the second column of Table 5 are mostly insignificant except for four (mostly commodity intensive) sectors. This means that exporters do not pass on imported input price changes to foreign consumers. Given full pass-through rates in a majority of sectors on the imported input side (see Table 4), these insignificant CAE coefficients imply that an appreciation of the exporter currency (CHF) leads to higher profit margins due to cheaper imported inputs.

Table 6 provides additional insights with regard to PTM and cost-adjustment behaviour at the sectoral level in the long run. Consistent with the short-run results and in line with YANG (1997), the Machinery \& equipment and Precision instruments sectors are able to keep the export price in CHF stable by passing on exchange rate shocks completely to foreign clients. ${ }^{35}$ Conversely, the average exporter in the Textiles or Food \& beverages sectors engages at least partly in PTM (see column 1, Table 6), thereby stabilising local prices and absorbing some of the exchange rate movements in the mark-up.

The cost-adjustment coefficients CAE in the second column of Table 6 have no statistical significance in 11 out of 15 sectors mostly confirming the corresponding short-run CAE results described above. In sum, the cost-savings accrued on the inputs from the recent $\mathrm{CHF}$ appreciation period compensate for the partly squeezed profit margins on the export side. Therefore, we can conclude that in the vast majority of the investigated goods sectors firms do not adjust export prices in response to exchange rate driven changes of production costs. As price adjustments are costly and a large bulk of the production costs is incurred in CHF (including compensation of employees, see Table 3), Swiss exporters optimally

32 Food \& beverages, Rubber \& plastics products, Mineral products and Electrical machinery.

33 Mining \& quarrying, Paper products, Iron \& steel, Fabricated Metal products, Machinery \& equipment and Precision instruments.

34 Textiles, Chemicals \& pharmaceuticals and Communication equipment.

35 Moreover, full pass-through cannot be rejected for Mining \& quarrying, Rubber \& plastics and Fabricated metal products. 
Table 6: ERPT into Export Prices (in CHF and in Foreign Currency Units, FCU) Long-Run (with Import Weighted Exchange Rates)

\begin{tabular}{|c|c|c|c|c|c|c|}
\hline & \multicolumn{3}{|c|}{ In $\mathrm{CHF}$} & \multicolumn{2}{|c|}{ In FCU } \\
\hline & & $\begin{array}{l}\text { Direct } \\
\text { (PTM) }\end{array}$ & $\begin{array}{l}\text { Indirect } \\
\text { (CAE) }\end{array}$ & $\begin{array}{l}\text { Total (1 } \\
- \text { TPT) }\end{array}$ & $\begin{array}{l}\text { Direct } \\
\text { (DPT) }\end{array}$ & $\begin{array}{l}\text { Total } \\
\text { (TPT) }\end{array}$ \\
\hline 1 & Agriculture & $\begin{array}{c}-0.47 \\
(1.40)\end{array}$ & $\begin{array}{c}1.50 \\
(1.23)\end{array}$ & $\begin{array}{c}1.02 \\
(0.94)\end{array}$ & $\begin{array}{c}1.47 \\
(1.40)\end{array}$ & $\begin{array}{l}-0.03 \\
(0.95)\end{array}$ \\
\hline 2 & Mining \& quarrying & $\begin{array}{c}0.05^{\mathrm{b}} \\
(0.30)\end{array}$ & $\begin{array}{l}7.70^{a / b} \\
(0.72)\end{array}$ & $\begin{array}{l}7.75^{a / b} \\
(0.91)\end{array}$ & $\begin{array}{r}0.95^{\mathrm{a}} \\
(0.30)\end{array}$ & $\begin{array}{l}-6.75^{a / b} \\
(0.91)\end{array}$ \\
\hline 3 & Food \& beverages & $\begin{array}{l}0.48^{a / b} \\
(0.12)\end{array}$ & $\begin{array}{r}0.08^{\mathrm{b}} \\
(0.33)\end{array}$ & $\begin{array}{c}0.56 \\
(0.33)\end{array}$ & $\begin{array}{l}0.52^{\mathrm{a} / \mathrm{b}} \\
(0.12)\end{array}$ & $\begin{array}{c}0.45 \\
(0.32)\end{array}$ \\
\hline 4 & Textiles & $\begin{array}{c}0.78^{a} \\
(0.27)\end{array}$ & $\begin{array}{r}-0.38^{\mathrm{b}} \\
(0.43)\end{array}$ & $\begin{array}{c}0.40 \\
(0.38)\end{array}$ & $\begin{array}{r}0.22^{\mathrm{b}} \\
(0.27)\end{array}$ & $\begin{array}{c}0.60 \\
(0.39)\end{array}$ \\
\hline 5 & Wood products & $\begin{array}{c}0.69 \\
(0.36)\end{array}$ & $\begin{array}{r}1.25^{\mathrm{a}} \\
(0.44)\end{array}$ & $\begin{array}{l}1.94^{a / b} \\
(0.31)\end{array}$ & $\begin{array}{c}0.31 \\
(0.36)\end{array}$ & $\begin{array}{l}-0.95^{\mathrm{a} / \mathrm{b}} \\
(0.31)\end{array}$ \\
\hline 6 & Paper products & $\begin{array}{l}-0.23 \\
(0.68)\end{array}$ & $\begin{array}{c}0.33 \\
(0.87)\end{array}$ & $\begin{array}{c}0.11^{\mathrm{b}} \\
(0.34)\end{array}$ & $\begin{array}{c}1.23 \\
(0.68)\end{array}$ & $\begin{array}{r}0.89^{\mathrm{a}} \\
(0.34)\end{array}$ \\
\hline 7 & Chemicals \& pharmaceuticals & $\begin{array}{c}0.54 \\
(0.45)\end{array}$ & $\begin{array}{c}-0.70 \\
(1.44)\end{array}$ & $\begin{array}{c}-0.15 \\
(1.43)\end{array}$ & $\begin{array}{c}0.46 \\
(0.47)\end{array}$ & $\begin{array}{c}1.15 \\
(1.43)\end{array}$ \\
\hline 8 & Rubber $\&$ plastics products & $\begin{array}{r}0.32^{\mathrm{b}} \\
(0.28)\end{array}$ & $\begin{array}{l}2.20^{a / b} \\
(0.33)\end{array}$ & $\begin{array}{l}2.52^{a / b} \\
(0.31)\end{array}$ & $\begin{array}{r}0.68^{\mathrm{a}} \\
(0.28)\end{array}$ & $\begin{array}{l}-1.52^{\mathrm{a} / \mathrm{b}} \\
(0.31)\end{array}$ \\
\hline 9 & Mineral products & $\begin{array}{c}0.63 \\
(0.36)\end{array}$ & $\begin{array}{c}0.43 \\
(0.54)\end{array}$ & $\begin{array}{r}1.06^{\mathrm{a}} \\
(0.45)\end{array}$ & $\begin{array}{c}0.37 \\
(0.36)\end{array}$ & $\begin{array}{r}-0.06^{\mathrm{b}} \\
(0.45)\end{array}$ \\
\hline 10 & Iron $\&$ steel & $\begin{array}{c}0.51 \\
(0.60)\end{array}$ & $\begin{array}{c}-1.48^{a / b} \\
(0.62)\end{array}$ & $\begin{array}{r}-0.97^{\mathrm{b}} \\
(0.88)\end{array}$ & $\begin{array}{c}0.49 \\
(0.61)\end{array}$ & $\begin{array}{r}1.97^{\mathrm{a}} \\
(0.88)\end{array}$ \\
\hline 11 & Fabricated metal products & $\begin{array}{r}0.32^{\mathrm{b}} \\
(0.18)\end{array}$ & $\begin{array}{r}1.18^{\mathrm{a}} \\
(0.32)\end{array}$ & $\begin{array}{r}1.50^{\mathrm{a}} \\
(0.30)\end{array}$ & $\begin{array}{r}0.68^{\mathrm{a}} \\
(0.18)\end{array}$ & $\begin{array}{r}-0.50^{\mathrm{b}} \\
(0.30)\end{array}$ \\
\hline 12 & Machinery \& equipment & $\begin{array}{c}0.02^{\mathrm{b}} \\
(0.38)\end{array}$ & $\begin{array}{c}-0.46 \\
(0.73)\end{array}$ & $\begin{array}{r}-0.44^{b} \\
(0.66)\end{array}$ & $\begin{array}{r}0.98^{\mathrm{a}} \\
(0.38)\end{array}$ & $\begin{array}{r}1.44^{\mathrm{a}} \\
(0.66)\end{array}$ \\
\hline 13 & Electrical machinery & $\begin{array}{c}0.72 \\
(0.43)\end{array}$ & $\begin{array}{c}1.37 \\
(0.87)\end{array}$ & $\begin{array}{r}2.10^{\mathrm{a}} \\
(0.95)\end{array}$ & $\begin{array}{c}0.28 \\
(0.43)\end{array}$ & $\begin{array}{r}-1.10^{\mathrm{b}} \\
(0.95)\end{array}$ \\
\hline 14 & Communication equipment & $\begin{array}{c}0.96 \\
(0.64)\end{array}$ & $\begin{array}{c}-0.75 \\
(1.24)\end{array}$ & $\begin{array}{c}0.21 \\
(1.54)\end{array}$ & $\begin{array}{c}0.04 \\
(0.64)\end{array}$ & $\begin{array}{c}0.79 \\
(1.54)\end{array}$ \\
\hline 15 & Precision instruments & $\begin{array}{c}0.06^{\mathrm{b}} \\
(0.19)\end{array}$ & $\begin{array}{r}-0.85^{\mathrm{b}} \\
(0.84)\end{array}$ & $\begin{array}{r}-0.79^{\mathrm{b}} \\
(0.84)\end{array}$ & $\begin{array}{r}0.94^{\mathrm{a}} \\
(0.19)\end{array}$ & $\begin{array}{r}1.79^{\mathrm{a}} \\
(0.84)\end{array}$ \\
\hline
\end{tabular}

Notes: PTM (pricing to market coefficient $)=\Sigma_{t=0}^{-2} \gamma_{1, t}^{s o}$, CAE (cost-adjustment effect) $=$ $\Sigma_{t=0}^{-2} \gamma_{2, t}^{s o}, 1-\mathrm{TPT}=\Sigma_{t=0}^{-2}\left(\gamma_{1, t}^{s o}+\gamma_{2, t}^{s o}\right), \mathrm{DPT}=1-\Sigma_{t=0}^{-2} \gamma_{1, t}^{s o}$, TPT (total pass-through coefficient $)=1-\Sigma_{t=0}^{-2}\left(\gamma_{1, t}^{s o}+\gamma_{2, t}^{s o}\right) ;{ }^{a / b} \mathrm{H} 0$ of zero/one PTM, CAE or pass-through (DPT and TPT) rejected at the 95\%-level, respectively; estimated with weighted least squares (weight = export value), robust-clustered standard errors in parentheses (cluster unit = partner country); phase-source varying fixed effects as well as $h s 6$ varying fixed effects. 
choose to absorb changes of the imported input prices in their mark-ups. Moreover, the relationship between import intensity and DPT displayed in Figure 1 (based on Table 6), also corroborates the main findings in Аміті, Iтsкнокі and Konings (2012): sectors that import a large share of their inputs pass on a much smaller share of the exchange rate shock to export prices. The negative relationship between the share of imported inputs and DPT can also be easily depicted in a general model of international pricing, as done by Burstein and Gopinath (2013). Intuitively, it should be clear that the higher the share of imported inputs that are invoiced in the export currency, the less an exchange rate appreciation would really constitute a cost "shock" anymore, as also argued by GolDBERG and Hellerstein (2008). As a result, sectors with higher shares of imported inputs do not require to pass on exchange rate movements in the same amount as sectors relying less on imported inputs. ${ }^{36}$

As with the import estimations, we also tested whether pricing behaviour on the export side differed during the "strong Franc" period and again found no convincing support for this hypothesis. Thus, our results also hold for the period of the recent $\mathrm{CHF}$ appreciation.

Furthermore, we performed estimations with a less restrictive specification to check the sensitivity of the export results (see Table 9 and 10 in the Appendix). Specifically, hs2-products $*$ partner country fixed effects and time dummies replace again time phase $*$ partner country dummies. We have also added the first difference of $\log$ GDP and log inflation of partner countries to account for demand and price fluctuations in the destination countries. The results turn out to be strikingly similar to our main specification.

Lastly, we exploit our multiple export destination data to check whether ERPT is also driven by destination-specific characteristics. Specifically, we interact the bilateral exchange rate and the imported input weighted exchange rate with regional dummies corresponding to the Euro-zone, European non-Euro countries, the US, BRICS and the remaining OECD countries. The results from this robustness check, reported in Table 7, reveal that there are more than a few sectors for which some regions have a significantly positive coefficient whereas other regions have a significantly negative coefficient (e.g. PTM sectors 1, 2, 3, 5, 8 and 9; CAE sectors 5 and 6). This said, the US-sectors exhibit lower ERPT, which may be attributed to the US as a competitive destination market or the fact that most US import goods are invoiced in dollars (Gopinath, IтsкhокI

36 Although we control for imported weighted exchange rates in our regression, we do not control for the share of imported inputs. As a result, the interpretation that for sectors with higher foreign input shares an appreciation means a smaller cost shock is valid in our framework. 
Figure 1

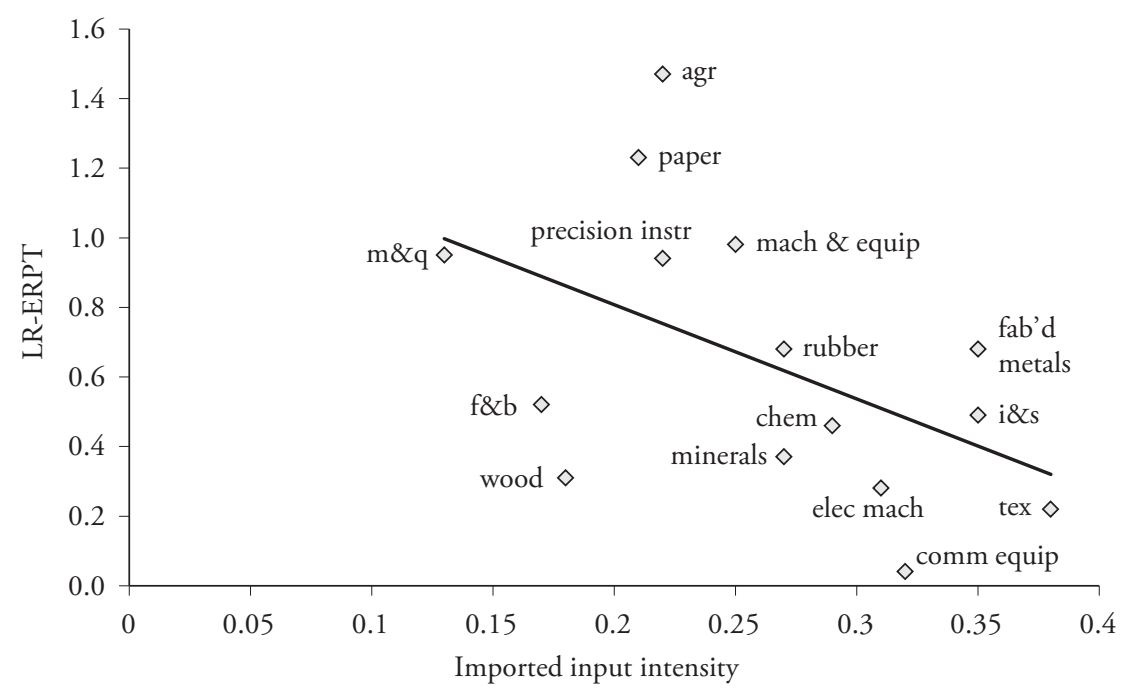

and Rigobon, 2010). ${ }^{37}$ Moreover, cost reactions remain overwhelmingly insignificant, which implies that imported input cost changes mostly do not affect export pricing as in our main specification.

\section{Conclusions}

This paper uses highly disaggregated trade data for Switzerland over 2004-2011 to examine whether Swiss exporters systematically respond to exchange rate changes by adjusting their prices. Of underlying significance is the impact of exchange rate changes on the prices of imported inputs as the latter may serve as a "natural" channel by which exporters can maintain their competitive advantage despite an appreciation of the CHF, given the high share of imported intermediates in total intermediate inputs in Swiss manufacturing.

Our empirical results, that are impervious to various robustness checks, firstly indicate full ERPT into imported input prices in a majority of sectors. This provides evidence for the effectiveness of natural hedging. On the export side, our

37 The lower ERPT in the US is already well-documented in the literature (see for example CAMPA and Goldberg, 2005). 


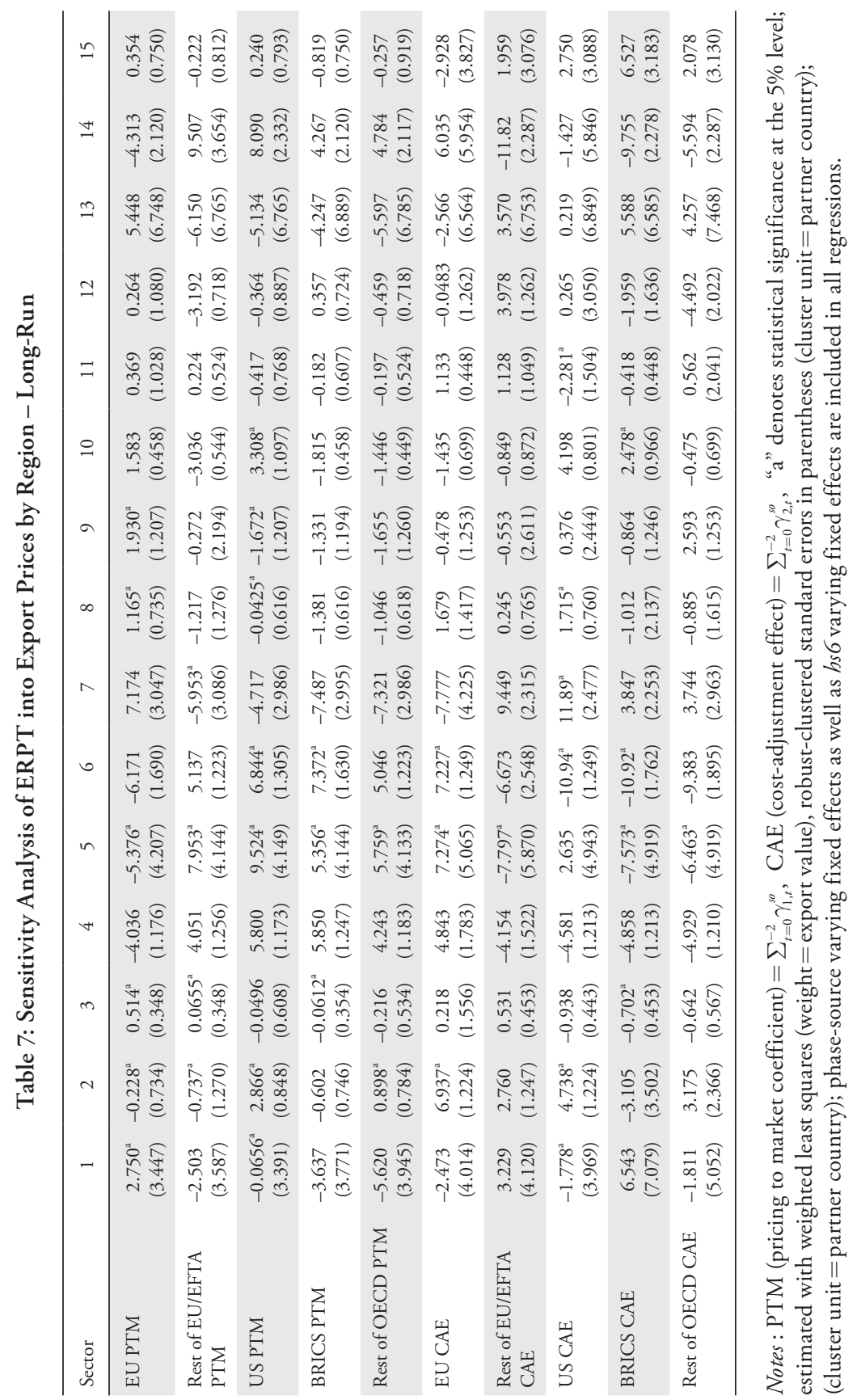


results indicate strong sectoral ERPT heterogeneity in both the short- and longrun. Moreover, the cost-adjustment effects are mostly insignificant implying that exporters do not pass on imported input price changes to foreign consumers. Thus, an appreciation of the CHF leads to higher profit margins through the import channel. The improved profit situation due to cheaper imported inputs partly compensates for mark-up reductions caused by incomplete ERPT when the currency appreciates. In contrast, a depreciating exchange rate makes imported inputs more expensive and these higher costs are not reflected in the export prices. As a result, natural hedging is likely to lead to a smoothing of profit margins in times of exchange rate volatility.

The evidence provided for the exchange rate sensitivity of input prices supports imported inputs as an explanation of incomplete ERPT. Without pass-through into input prices, imported inputs could not generate incomplete ERPT. In addition, our results indicate a negative relationship between sectoral import intensity and ERPT on the export side. This is consistent with previous literature. The last robustness check also suggests that ERPT does not systematically differ across destinations using border prices that are arguably unaffected by local nontraded costs. Thus, export border prices available across destinations helped us to isolate the imported input channel from destination-specific explanations of incomplete ERPT such as distribution or other non-traded costs denominated in local-currency.

The appreciation of the CHF began in 2009 and progressed steadily until the middle of 2010 after which it accelerated in response to the ensuing Eurozone crisis. During much of 2012, the Swiss National Bank (SNB) intervened to assuage Swiss exporters of the adverse effects of this appreciation. However, our final empirical result suggests that the pricing strategies of Swiss exporters may not have changed in response to the strong CHF in wake of the Eurozone crisis.

Future research could address the data limitations of our paper. While we could not identify changes in the pricing strategy of Swiss firms during the recent strong CHF period, such adjustment may be observed over a longer time period. We also did not directly investigate whether our results are partly driven by extensive margin adjustments, which being the case renders central bank intervention both appropriate and necessary to avoid irreversible structural damage of the exporting industry as emphasized by hysteresis theories (see for instance BALDwin and Krugman, 1989). Finally, it would be useful to extend our analysis to an enlarged country sample. To the extent that our results hold across countries and at the extensive margin, they would also have significant implications for monetary policy and for the policy debate on the impact of exchange rate misalignments on trade imbalances. 


\section{Appendix}

Table 8: ERPT Into Imported Input Prices (in CHF)

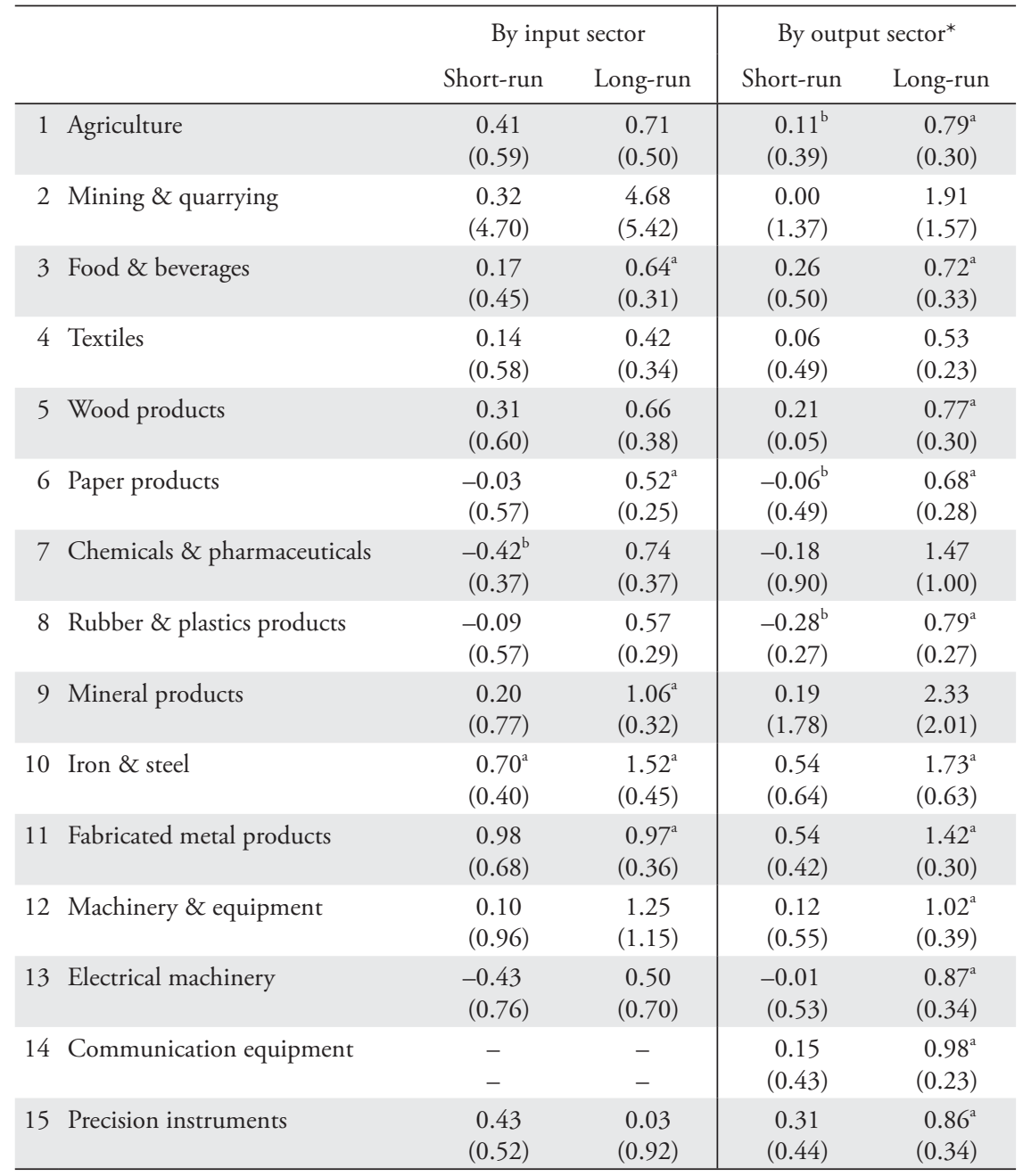

Notes: ${ }^{*}$ Weighted average ERPT faced by each output sector (weights from I-O table); by input sector: short-run $=\beta_{0}^{s i}$, long-run $=\sum_{t=0}^{-2} \beta_{t}^{s i}$; by output sector: short-run $=\beta_{0}^{s o}$, longrun $=\Sigma_{t=0}^{-2} \beta_{t}^{s o} ;{ }^{a / b} \mathrm{H} 0$ of zero/full pass-through rejected at the $95 \%$-level; estimated with WLS (weight $=$ import value), robust-clustered standard errors in parentheses (cluster unit $=$ source country); hs2-source varying fixed effects, time dummies and first difference of log inflation in source countries are used as control variables; coefficients missing for input sector 14 as no hs 8 input product classified within sector 14 . 
Table 9: ERPT into Export Prices (in CHF and in Foreign Currency Units, FCU) Short-Run (with Import Weighted Exchange Rates)

\begin{tabular}{|c|c|c|c|c|c|c|}
\hline & \multicolumn{3}{|c|}{ In $\mathrm{CHF}$} & \multicolumn{2}{|c|}{ In FCU } \\
\hline & & $\begin{array}{l}\text { Direct } \\
\text { (PTM) }\end{array}$ & $\begin{array}{c}\text { Indirect } \\
\text { (CAE) }\end{array}$ & $\begin{array}{c}\text { Total } \\
(1-\mathrm{TPT})\end{array}$ & $\begin{array}{l}\text { Direct } \\
\text { (DPT) }\end{array}$ & $\begin{array}{c}\text { Total } \\
\text { (TPT) }\end{array}$ \\
\hline 1 & Agriculture & $\begin{array}{c}-0.54 \\
(0.85)\end{array}$ & $\begin{array}{c}1.07 \\
(0.92)\end{array}$ & $\begin{array}{l}0.54 \\
0.31\end{array}$ & $\begin{array}{l}1.54 \\
0.85\end{array}$ & $\begin{array}{l}0.46 \\
0.31\end{array}$ \\
\hline 2 & Mining \& quarrying & $\begin{array}{l}-0.22^{\mathrm{b}} \\
(0.226)\end{array}$ & $\begin{array}{l}1.49^{a / b} \\
(0.30)\end{array}$ & $\begin{array}{r}1.26^{\mathrm{a}} \\
(0.30)\end{array}$ & $\begin{array}{r}1.22^{\mathrm{a}} \\
(0.23)\end{array}$ & $\begin{array}{c}-0.28^{\mathrm{b}} \\
0.30\end{array}$ \\
\hline 3 & Food $\&$ beverages & $\begin{array}{l}0.47^{\mathrm{a} / \mathrm{b}} \\
(0.15)\end{array}$ & $\begin{array}{c}0.07^{\mathrm{b}} \\
(0.13)\end{array}$ & $\begin{array}{l}0.54^{a / b} \\
(0.08)\end{array}$ & $\begin{array}{l}0.53^{\mathrm{a} / \mathrm{b}} \\
(0.15)\end{array}$ & $\begin{array}{c}0.46^{a / b} \\
(0.08)\end{array}$ \\
\hline 4 & Textiles & $\begin{array}{c}0.72^{\mathrm{a}} \\
(0.23)\end{array}$ & $\begin{array}{r}-0.63^{\mathrm{b}} \\
(0.33)\end{array}$ & $\begin{array}{c}0.09^{\mathrm{b}} \\
(0.17)\end{array}$ & $\begin{array}{c}0.28^{\mathrm{b}} \\
(0.23)\end{array}$ & $\begin{array}{c}0.91^{\mathrm{a}} \\
(0.17)\end{array}$ \\
\hline 5 & Wood products & $\begin{array}{c}0.60 \\
(0.30)\end{array}$ & $\begin{array}{c}0.30 \\
(0.37)\end{array}$ & $\begin{array}{r}0.90^{\mathrm{a}} \\
(0.21)\end{array}$ & $\begin{array}{c}0.40 \\
(0.30)\end{array}$ & $\begin{array}{c}0.10^{\mathrm{b}} \\
(0.21)\end{array}$ \\
\hline 6 & Paper products & $\begin{array}{c}0.60^{\mathrm{b}} \\
(0.30)\end{array}$ & $\begin{array}{r}0.04^{\mathrm{b}} \\
(0.25)\end{array}$ & $\begin{array}{r}0.17^{\mathrm{b}} \\
(0.15)\end{array}$ & $\begin{array}{r}0.87^{\mathrm{a}} \\
(0.17)\end{array}$ & $\begin{array}{r}0.83^{a} \\
(0.15)\end{array}$ \\
\hline 7 & Chemicals \& pharmaceuticals & $\begin{array}{r}0.92^{\mathrm{a}} \\
(0.19)\end{array}$ & $\begin{array}{c}0.44 \\
(0.29)\end{array}$ & $\begin{array}{r}1.37^{\mathrm{a}} \\
(0.37)\end{array}$ & $\begin{array}{c}0.08^{\mathrm{b}} \\
(0.19)\end{array}$ & $\begin{array}{c}-0.37^{\mathrm{b}} \\
(0.37)\end{array}$ \\
\hline 8 & Rubber \& plastics products & $\begin{array}{l}0.38^{\mathrm{a} / \mathrm{b}} \\
(0.15)\end{array}$ & $\begin{array}{c}-0.11 \\
(0.23)\end{array}$ & $\begin{array}{l}0.27^{\mathrm{a} / \mathrm{b}} \\
(0.13)\end{array}$ & $\begin{array}{l}0.62^{a / b} \\
(0.15)\end{array}$ & $\begin{array}{c}0.73^{a / b} \\
(0.13)\end{array}$ \\
\hline 9 & Mineral products & $\begin{array}{l}0.62^{a / b} \\
(0.16)\end{array}$ & $\begin{array}{r}-0.09^{\mathrm{b}} \\
(0.22)\end{array}$ & $\begin{array}{l}0.54^{\mathrm{a} / \mathrm{b}} \\
(0.21)\end{array}$ & $\begin{array}{l}0.37^{\mathrm{a} / \mathrm{b}} \\
(0.16)\end{array}$ & $\begin{array}{c}0.46^{\text {a/b }} \\
(0.21)\end{array}$ \\
\hline 10 & Iron $\&$ steel & $\begin{array}{c}-1.11^{\mathrm{a} / \mathrm{b}} \\
(0.51)\end{array}$ & $\begin{array}{l}2.65^{\mathrm{a} / \mathrm{b}} \\
(0.41)\end{array}$ & $\begin{array}{c}1.54^{\mathrm{a}} \\
(0.37)\end{array}$ & $\begin{array}{c}2.11^{\mathrm{a} / \mathrm{b}} \\
(0.51)\end{array}$ & $\begin{array}{c}-0.54^{\mathrm{b}} \\
(0.37)\end{array}$ \\
\hline 11 & Fabricated metal products & $\begin{array}{r}0.25^{\mathrm{b}} \\
(0.14)\end{array}$ & $\begin{array}{r}0.19^{\mathrm{b}} \\
(0.15)\end{array}$ & $\begin{array}{l}0.44^{\mathrm{a} b \mathrm{~b}} \\
(0.12)\end{array}$ & $\begin{array}{r}0.75^{\mathrm{a}} \\
(0.14)\end{array}$ & $\begin{array}{c}0.56^{a / b} \\
(0.12)\end{array}$ \\
\hline 12 & Machinery \& equipment & $\begin{array}{c}0.08^{\mathrm{b}} \\
(0.28)\end{array}$ & $\begin{array}{r}0.26^{\mathrm{b}} \\
(0.24)\end{array}$ & $\begin{array}{c}0.34^{a / b} \\
(0.17)\end{array}$ & $\begin{array}{r}0.92^{\mathrm{a}} \\
(0.28)\end{array}$ & $\begin{array}{c}0.66^{a / b} \\
(0.17)\end{array}$ \\
\hline 13 & Electrical machinery & $\begin{array}{l}0.43^{a / b} \\
(0.14)\end{array}$ & $\begin{array}{r}0.25^{\mathrm{b}} \\
(0.17)\end{array}$ & $\begin{array}{l}0.68^{a / b} \\
(0.12)\end{array}$ & $\begin{array}{l}0.57^{a / b} \\
0.14\end{array}$ & $\begin{array}{l}0.32^{a / b} \\
(0.12)\end{array}$ \\
\hline 14 & Communication equipment & $\begin{array}{c}0.64 \\
(0.35)\end{array}$ & $\begin{array}{c}0.03^{\mathrm{b}} \\
(0.57)\end{array}$ & $\begin{array}{c}0.66^{\mathrm{b}} \\
(0.49)\end{array}$ & $\begin{array}{l}(0.36) \\
(0.35)\end{array}$ & $\begin{array}{c}0.38^{\mathrm{a}} \\
(0.49)\end{array}$ \\
\hline 15 & Precision instruments & $\begin{array}{c}0.20^{\mathrm{b}} \\
(0.12)\end{array}$ & $\begin{array}{c}0.23^{\mathrm{b}} \\
(0.14)\end{array}$ & $\begin{array}{l}0.43^{a / b} \\
(0.14)\end{array}$ & $\begin{array}{r}0.80^{\mathrm{a}} \\
(0.12)\end{array}$ & $\begin{array}{c}0.57^{a / b} \\
(0.14)\end{array}$ \\
\hline
\end{tabular}

Notes: PTM (pricing to market coefficient),$=\gamma_{1,0}^{s o}$, CAE (cost-adjustment effect) $=\gamma_{2,0}^{s o}$, $1-\mathrm{TPT}=\gamma_{1,0}^{s o}+\gamma_{2,0}^{s o}, \mathrm{DPT}=1-\gamma_{1,0}^{s o}, \mathrm{TPT}$ (total pass-through coefficient $)=1-\left(\gamma_{1,0}^{s,}+\gamma_{2,0}^{s o}\right)$;

${ }^{a / b} \mathrm{H} 0$ of zero/one PTM, CAE or pass-through (DPT and TPT) rejected at the $95 \%$-level, respectively; estimated with weighted least squares (weight $=$ export value), robust-clustered standard errors in parentheses (cluster unit = partner country); $h s 2$-partner country varying fixed effects, time dummies and first difference of log inflation and log GDP in partner countries are used as control variables. 


\section{Table 10: ERPT into Export Prices (in CHF and in Foreign Currency Units, FCU) - Long-Run (with Import Weighted Exchange Rates)}

\begin{tabular}{|c|c|c|c|c|c|c|}
\hline & \multicolumn{3}{|c|}{ In $\mathrm{CHF}$} & \multicolumn{2}{|c|}{ In FCU } \\
\hline & & $\begin{array}{l}\text { Direct } \\
\text { (PTM) }\end{array}$ & $\begin{array}{l}\text { Indirect } \\
\text { (CAE) }\end{array}$ & $\begin{array}{c}\text { Total } \\
(1-\mathrm{TPT})\end{array}$ & $\begin{array}{l}\text { Direct } \\
(\mathrm{DPT})\end{array}$ & $\begin{array}{l}\text { Total } \\
\text { (TPT) }\end{array}$ \\
\hline & Agriculture & $\begin{array}{r}-0.48 \\
0.91\end{array}$ & $\begin{array}{c}0.59 \\
(1.26)\end{array}$ & $\begin{array}{c}0.11 \\
(0.64)\end{array}$ & $\begin{array}{c}1.48 \\
(0.90)\end{array}$ & $\begin{array}{c}0.89 \\
(0.64)\end{array}$ \\
\hline 2 & Mining \& quarrying & $\begin{array}{l}-1.17^{\mathrm{a} / \mathrm{b}} \\
(0.42)\end{array}$ & $\begin{array}{l}3.69^{a / b} \\
(0.55)\end{array}$ & $\begin{array}{l}2.51^{a / b} \\
(0.33)\end{array}$ & $\begin{array}{l}2.17^{\mathrm{a} / \mathrm{b}} \\
(0.42)\end{array}$ & $\begin{array}{c}-1.51^{a / b} \\
(0.33)\end{array}$ \\
\hline 3 & Food $\&$ beverages & $\begin{array}{l}0.61^{a / b} \\
(0.12)\end{array}$ & $\begin{array}{l}0.44^{a / b} \\
(0.17)\end{array}$ & $\begin{array}{l}1.04^{\mathrm{a}} \\
0.12\end{array}$ & $\begin{array}{l}0.39^{\mathrm{a} / \mathrm{b}} \\
(0.12)\end{array}$ & $\begin{array}{c}-0.04^{b} \\
0.12\end{array}$ \\
\hline 4 & Textiles & $\begin{array}{r}0.74^{\mathrm{a}} \\
(0.19)\end{array}$ & $\begin{array}{c}-0.19^{\mathrm{b}} \\
(0.23)\end{array}$ & $\begin{array}{l}0.56^{a / b} \\
0.10\end{array}$ & $\begin{array}{r}0.26^{\mathrm{b}} \\
(0.19)\end{array}$ & $\begin{array}{l}0.44^{a / b} \\
(0.10)\end{array}$ \\
\hline 5 & Wood products & $\begin{array}{c}0.78 \\
(0.47)\end{array}$ & $\begin{array}{c}-0.14^{\mathrm{b}} \\
(0.45)\end{array}$ & $\begin{array}{l}0.63^{a / b} \\
(0.13)\end{array}$ & $\begin{array}{c}0.22 \\
(0.47)\end{array}$ & $\begin{array}{l}0.37^{a / b} \\
(0.13)\end{array}$ \\
\hline 6 & Paper products & $\begin{array}{r}0.06^{\mathrm{b}} \\
(0.19)\end{array}$ & $\begin{array}{r}0.28^{\mathrm{b}} \\
(0.19)\end{array}$ & $\begin{array}{l}0.35^{a / b} \\
(0.12)\end{array}$ & $\begin{array}{r}0.94^{\mathrm{a}} \\
(0.19)\end{array}$ & $\begin{array}{l}0.654^{a / b} \\
(0.12)\end{array}$ \\
\hline 7 & Chemicals \& pharmaceuticals & $\begin{array}{r}1.03^{\mathrm{a}} \\
(0.40)\end{array}$ & $\begin{array}{c}-0.04^{b} \\
(0.61)\end{array}$ & $\begin{array}{r}0.99^{a} \\
(0.38)\end{array}$ & $\begin{array}{c}-0.03^{\mathrm{b}} \\
(0.40)\end{array}$ & $\begin{array}{c}0.01^{\mathrm{b}} \\
(0.38)\end{array}$ \\
\hline 8 & Rubber \& plastics products & $\begin{array}{c}0.46^{a / b} \\
(0.17)\end{array}$ & $\begin{array}{r}0.29^{\mathrm{b}} \\
(0.19)\end{array}$ & $\begin{array}{l}0.75^{a / b} \\
(0.09)\end{array}$ & $\begin{array}{l}0.54^{\mathrm{a} / \mathrm{b}} \\
(0.17)\end{array}$ & $\begin{array}{l}0.25^{5^{a / b}} \\
(0.09)\end{array}$ \\
\hline 9 & Mineral products & $\begin{array}{c}0.45^{\mathrm{b}} \\
(0.24)\end{array}$ & $\begin{array}{c}0.14^{\mathrm{b}} \\
(0.26)\end{array}$ & $\begin{array}{l}0.59^{a / b} \\
(0.21)\end{array}$ & $\begin{array}{c}0.55^{\mathrm{a}} \\
(0.24)\end{array}$ & $\begin{array}{l}0.42^{\mathrm{a} / \mathrm{b}} \\
(0.21)\end{array}$ \\
\hline 10 & Iron \& steel & $\begin{array}{c}-0.85^{\mathrm{b}} \\
0.45\end{array}$ & $\begin{array}{r}2.17^{\mathrm{a}} \\
(0.38)\end{array}$ & $\begin{array}{r}1.32^{\mathrm{a}} \\
(0.24)\end{array}$ & $\begin{array}{r}1.85^{\mathrm{a}} \\
(0.45)\end{array}$ & $\begin{array}{r}-0.32^{\mathrm{b}} \\
(0.24)\end{array}$ \\
\hline 11 & Fabricated metal products & $\begin{array}{l}0.35^{\mathrm{a} / \mathrm{b}} \\
(0.08)\end{array}$ & $\begin{array}{r}0.57^{\mathrm{a}} \\
(0.14)\end{array}$ & $\begin{array}{r}0.92^{\mathrm{a}} \\
(0.12)\end{array}$ & $\begin{array}{l}0.65^{\mathrm{a} / \mathrm{b}} \\
(0.08)\end{array}$ & $\begin{array}{r}0.08^{\mathrm{b}} \\
(0.12)\end{array}$ \\
\hline 12 & Machinery \& equipment & $\begin{array}{c}-0.27^{\mathrm{b}} \\
(0.32)\end{array}$ & $\begin{array}{c}0.24 \\
(0.43)\end{array}$ & $\begin{array}{c}-0.03^{\mathrm{b}} \\
(0.28)\end{array}$ & $\begin{array}{r}1.27^{\mathrm{a}} \\
(0.32)\end{array}$ & $\begin{array}{r}1.03^{\mathrm{a}} \\
(0.28)\end{array}$ \\
\hline 13 & Electrical machinery & $\begin{array}{r}0.43^{\mathrm{b}} \\
(0.24)\end{array}$ & $\begin{array}{c}0.51 \\
(0.32)\end{array}$ & $\begin{array}{r}0.93^{\mathrm{a}} \\
(0.36)\end{array}$ & $\begin{array}{r}0.57^{\mathrm{a}} \\
(0.24)\end{array}$ & $\begin{array}{r}0.06^{\mathrm{b}} \\
(0.36)\end{array}$ \\
\hline 14 & Communication equipment & $\begin{array}{c}0.35 \\
(0.47)\end{array}$ & $\begin{array}{c}0.64 \\
(0.89)\end{array}$ & $\begin{array}{c}0.99 \\
(0.88)\end{array}$ & $\begin{array}{c}0.65 \\
(0.47)\end{array}$ & $\begin{array}{c}0.01 \\
(0.88)\end{array}$ \\
\hline & Precision instruments & $\begin{array}{c}0.15^{\mathrm{b}} \\
(0.08)\end{array}$ & $\begin{array}{c}-0.05 \\
(0.33)\end{array}$ & $\begin{array}{r}0.10^{\mathrm{b}} \\
(0.30)\end{array}$ & $\begin{array}{r}0.85^{\mathrm{a}} \\
(0.08)\end{array}$ & $\begin{array}{r}0.90^{\mathrm{a}} \\
(0.30)\end{array}$ \\
\hline
\end{tabular}

Notes: PTM (pricing to market coefficient $)=\Sigma_{t=0}^{-2} \gamma_{1, t}^{s o}$, CAE (cost-adjustment effect) $=$ $\sum_{t=0}^{-2} \gamma_{2, t}^{s o}, 1-\mathrm{TPT}=\Sigma_{t=0}^{-2}\left(\gamma_{1, t}^{s o}+\gamma_{2, t}^{s o}\right), \mathrm{DPT}=1-\Sigma_{t=0}^{-2} \gamma_{1, t}^{s o}$, TPT (total pass-through coefficient $)=1-\Sigma_{t=0}^{-2}\left(\gamma_{1, t}^{s o}+\gamma_{2, t}^{s o}\right) ;{ }^{a / b} \mathrm{H} 0$ of zero/one PTM, CAE or pass-through (DPT and TPT) rejected at the 95\%-level, respectively; estimated with weighted least squares (weight = export value), robust-clustered standard errors in parentheses (cluster unit = partner country); hs2partner country varying fixed effects, time dummies and first difference of log inflation and log GDP in partner countries are used as control variables. 


\section{References}

Aksoy, Y., and Y. E. Riyanto (2000), "Exchange Rate Pass-Through in Vertically Related Markets", Review of International Economics, 8(2), pp. 135-251. Amiti, Mary, Oleg Itskhoki, and Jozef Konings (2012), "Importers, Exporters, and Exchange Rate Disconnect", NBER Working Paper No 18615.

Antràs, Pol (2011), "Grossman-Hart (1986) Goes Global: Incomplete Contracts, Property Rights, and the International Organization of Production", NBER Working paper.

Athukorala, P., and J. Menon (1994), "Pricing to Market Behaviour and Exchange Rate Pass-Through in Japanese Exports", Economic Journal, 104 (423), pp. 171-281.

Atreson, A., and A. Burstein (2008), "Pricing-to-Market, Trade Costs, and International Relative Prices", American Economic Review, 98(5), pp. 1998-2031.

Auer, R., and T. Chaney (2009), "Exchange Rate Pass-Through in a Competitive Model of Pricing-to-Market", Journal of Money, Credit and Banking, 41, pp. 151-175.

Baldwin, R., and P. R. Krugman (1989), "Persistent Trade Effects of Large Exchange Rate Shocks”, Quarterly Journal of Economics, 104(4), pp. 135-654.

Berman, N., P. Martin, and T. Mayer (2012), "How Do Different Exporters React to Exchange Rate Changes?", Quarterly Journal of Economics, 127(1), pp. 137-492.

Burstein, Ariel and Gita Gopinath (2013), "International Prices and Exchange Rates", NBER Working paper No 18829.

Campa, J., and L. S. Goldberg (1995), "Investment in Manufacturing, Exchange Rates and External Exposure", Journal of International Economics, 38(3-4), pp. 197-320.

Campa, J., and L. S. Goldberg (1997), "The Evolving External Orientation of Manufacturing Industries: Evidence from Four Countries", National Bureau of Economic Research Working Paper Series.

Campa, J. M., and L. S. Goldberg (1999), "Investment, Pass-Through, and Exchange Rates: A Cross-Country Comparison”, International Economic Review, 40(2), pp. 187-314.

Campa, J. M., and L. S. Goldberg (2005), "Exchange Rate Pass-Through into Import Prices", Review of Economics and Statistics, 87(4), pp. 179-690.

Campa, J. M. and J.M. Gonzalez Minguez (2006), "Differences in Exchange Rate Pass-Through in the Euro Area", European Economic Review, 50(1), pp. 121-145. 
Corsetti, G., and L. Dedola (2005), "A Macroeconomic Model of International Price Discrimination", Journal of International Economics, 67(1), pp. 129-155.

Dornbusch, R. (1987), "Exchange Rates and Prices", American Economic Review, 77(1), 93-106.

Gaulier, G., A. Lahrèche-Révil, and I. Méjean (2006), "Structural Determinants of the Exchange-Rate Pass-Through", CEPII Working Papers.

Gaulier, G., A. Lahrèche-Révil, and I. Méjean (2008), "Exchange-Rate PassThrough at the Product Level", Canadian Journal of Economics/Revue canadienne d'économique, 41(2), pp. 125-449.

Goldberg, L. S., and J. M. Campa (2010), "The Sensitivity of the CPI to Exchange Rates: Distribution Margins, Imported Inputs, and Trade Exposure", Review of Economics and Statistics, 92(2), pp. 192-407.

Goldberg, Pinelopi Koujianou, and Rebecca Hellerstein (2008), "A Structural Approach to Explaining Incomplete Exchange-Rate Pass-Through and Pricing-to-Market", American Economic Review, 98(2), pp. 123-429.

Goldberg, P. K. and M. M. Knetter (1997), "Goods Prices and Exchange Rates: What Have We Learned?", Journal of Economic Literature, 35(3), pp. 1243-1272.

Gopinath, G., O. Itsкhoкi, and R. Rigobon (2010), "Currency Choice and Exchange Rate Pass-Through", American Economic Review, 100(1), pp. 104-336.

Gopinath, G., and R. Rigobon (2008), "Sticky Borders", Quarterly Journal of Economics, 123(3), pp. 131-575.

Greenaway, D., R. Kneller, and X. Zhang (2010), "The Effect of Exchange Rates on Firm Exports: The Role of Imported Intermediate Inputs", World Economy, 33(8), pp. 161-986.

Hellerstein, Rebecca, and Sofia B. Villas-Boas (2010), "Outsourcing and Pass-Through", Journal of International Economics, 81(2), pp. 170-183.

Herger, Nils (2012), "Exchange Rates and Import Prices in Switzerland", Swiss Journal of Economics and Statistics (SJES), 148(III), pp. 181-407.

Hummels, D., J. IshiI, and K. M. YI (2001), "The Nature and Growth of Vertical Specialization in World Trade", Journal of International Economics, 54(1), pp. 15-96.

Ihrig, J., M. Marazzi, and A. Rothenberg (2006), "Exchange-Rate PassThrough in the G-7 Countries", FRB International Finance Discussion Paper No. 851.

Knetter, M. M. (1989), "Price Discrimination by US and German Exporters", American Economic Review, 79(1), pp. 198-210. 
Knetter, M. M. (1993), "International Comparisons of Pricing-to-Market Behavior”, American Economic Review, 83(3), pp. 173-486.

Melitz, M. J. and G. I. P. Ottaviano (2008), "Market Size, Trade, and Productivity", Review of Economic Studies, 75(1), pp. 195-316.

Neiman, Brent (2010), "Stickiness, Synchronization, and Passthrough in Intrafirm Trade Prices", Journal of Monetary Economics, 57(3), pp. 195-308.

OECD (2012), STAN Input-Output Database Total, Domestic and Imports (database), stats.oecd.org, OECD Paris.

Rangan, S., R. Z. Lawrence, and R. N. Cooper (1993), "The Responses of US Firms to Exchange Rate Fluctuations: Piercing the Corporate Veil”, Brookings Papers on Economic Activity, 1993(2), pp. 141-379.

SeCo (2011), „Weitergabe von Einkaufsvorteilen aufgrund der Frankenstärke“, Working paper.

Stulz, J. (2007), "Exchange Rate Pass-Through in Switzerland: Evidence from Vector Autoregressions", SNB Working paper.

YANG, J. (1997), "Exchange Rate Pass-Through in US Manufacturing Industries", Review of Economics and Statistics, 79(1), pp. 15-104.

\section{SUMMARY}

In this paper, we estimate ERPT into imported input prices and export prices using disaggregated quarterly trade data for Switzerland over 2004-2011. We find evidence for high pass-through rates into imported input prices. This demonstrates the effectiveness of natural hedging. On the export side, ERPT exhibits substantial sectoral heterogeneity and changes in imported input costs are not transmitted to foreign consumers in most cases. This suggests the use of cheaper imported inputs to offset adverse effects of currency appreciation on export profit margins. 